\title{
Geochemistry of a Triassic dyke swarm in the North Patagonian Massif, Argentina. Implications for a postorogenic event of the Permian Gondwanide orogeny
}

\author{
Santiago N. González a, *, Gerson A. Greco a, Pablo D. González a , Ana M. Sato b, \\ Eduardo J. Llambías ${ }^{\text {b }}$, Ricardo Varela ${ }^{\text {b }}$ \\ a Instituto de Investigación en Paleobiología y Geología (UNRN-CONICET), Av. Julio A. Roca 1242, R 8332 EXZ, General Roca, Río Negro, Argentina \\ ${ }^{\mathrm{b}}$ Centro de Investigaciones Geológicas (UNLP-CONICET), Calle 1 N 644, B 1900 TAC, La Plata, Buenos Aires, Argentina
}

\section{A R T I C L E I N F O}

\section{Article history:}

Received 21 November 2015

Received in revised form

10 April 2016

Accepted 25 April 2016

Available online 29 April 2016

\section{Keywords:}

Patagonia

Trachyandesite

Mildly alkaline

Extension

Postorogenic

\begin{abstract}
A B S T R A C T
Permo-Triassic magmatism is widespread in the eastern North Patagonian Massif and has been related to the Gondwanide orogeny. Although a magmatic arc setting is widely accepted for the Permian plutonic rocks, the origin and geotectonic setting for the Triassic plutonic and volcanic rocks are still unknown. A NW-SE Triassic dyke swarm composed of andesites and latites with minor rhyolites was previously described in the Sierra Grande - Rincon de Paileman area. The dyke swarm was associated with extensional tectonics which was linked to a postorogenic process.

In this paper we present new geochemical data of the rocks that form the swarm. Trachyandesites and rhyolites were separated based on their geochemical characteristics. Both groups may be considered originated from different sources. On the other hand, the content of incompatible elements (LILE and HFSE) indicates a strong relation between the swarm and an active continental margin. The samples also show a transitional signature between continental-arc and postcollisional or anorogenic settings.

The new geochemical data on the dyke swarm support the idea of a magmatism that was linked to a postorogenic extensional tectonic regime related to a continental magmatic arc. Such an extension started in the Paleopacific margin of Pangea during the Anisian and might indicate the beginning of the Pangea break-up.
\end{abstract}

(c) 2016 Elsevier Ltd. All rights reserved.

\section{Introduction}

The final stage of the amalgamation of Pangea was synchronous with the Gonwanide orogeny (305-230 Ma) which affected the Pacific subduction margin of Pangea (Keidel, 1921; Cawood, 2005; Cawood and Buchan, 2007). The Gondwanide orogeny involves compressive deformation accompanied by voluminous magmatism during the Carboniferous and Permian (Cawood, 2005; Cawood and Buchan, 2007 and references in there). This orogeny ends with an extensional process which is the beginning of Pangea break-up

\footnotetext{
* Corresponding author. Instituto de Investigación en Paleobiología y Geología (Universidad Nacional de Río Negro), Av. Julio A. Roca 1242, R 8332 EXZ, General Roca, Río Negro, Argentina.

E-mail addresses: sgonzalez@unrn.edu.ar (S.N. González), gersongreco@gmail. com (G.A. Greco), pdgonzalez@unrn.edu.ar (P.D. González), sato@cig.museo.unlp. edu.ar (A.M. Sato), llambias@cig.museo.unlp.edu.ar (E.J. Llambías), ricardovarela4747@gmail.com (R. Varela).
}

(Cawood and Buchan, 2007; Sato et al., 2015).

In Argentina and Chile, the Gondwanic orogenic axis and associated magmatic arc is arranged in a close $\mathrm{N}-\mathrm{S}$ belt north of the $38^{\circ} \mathrm{S}$ (Kay et al., 1989; Llambías and Sato, 2011). Southwards, in the North Patagonia, this belt is oriented near NW-SE direction (Fig. 1; Giacosa, 1987, 1993, 2001; Llambías and Rapela, 1984; Rapela and Llambías, 1985; von Gosen, 2002, 2009; Greco et al., 2015).

The arc-related magmatism associated to the Gondwanide orogeny has been recognized all over the Paleopacific margin of Pangea (Cawood and Buchan, 2007; Sato et al., 2015). In the eastern North Patagonian Massif this magmatism is entirely plutonic and range from 291 to 260 Ma (Varela et al., 2008, 2009, 2011; Pankhurst et al., 2006; García et al., 2014a). This Permian plutonic rocks and their country rocks are affected by Permian deformational structures related with a Gondwanide NE-SW compression (Ramos, 1975; Giacosa, 1987, 2001; Busteros et al., 1998; Japas, 2001; von Gosen, 2002; González et al., 2008, 2011; Greco et al., 2015). 


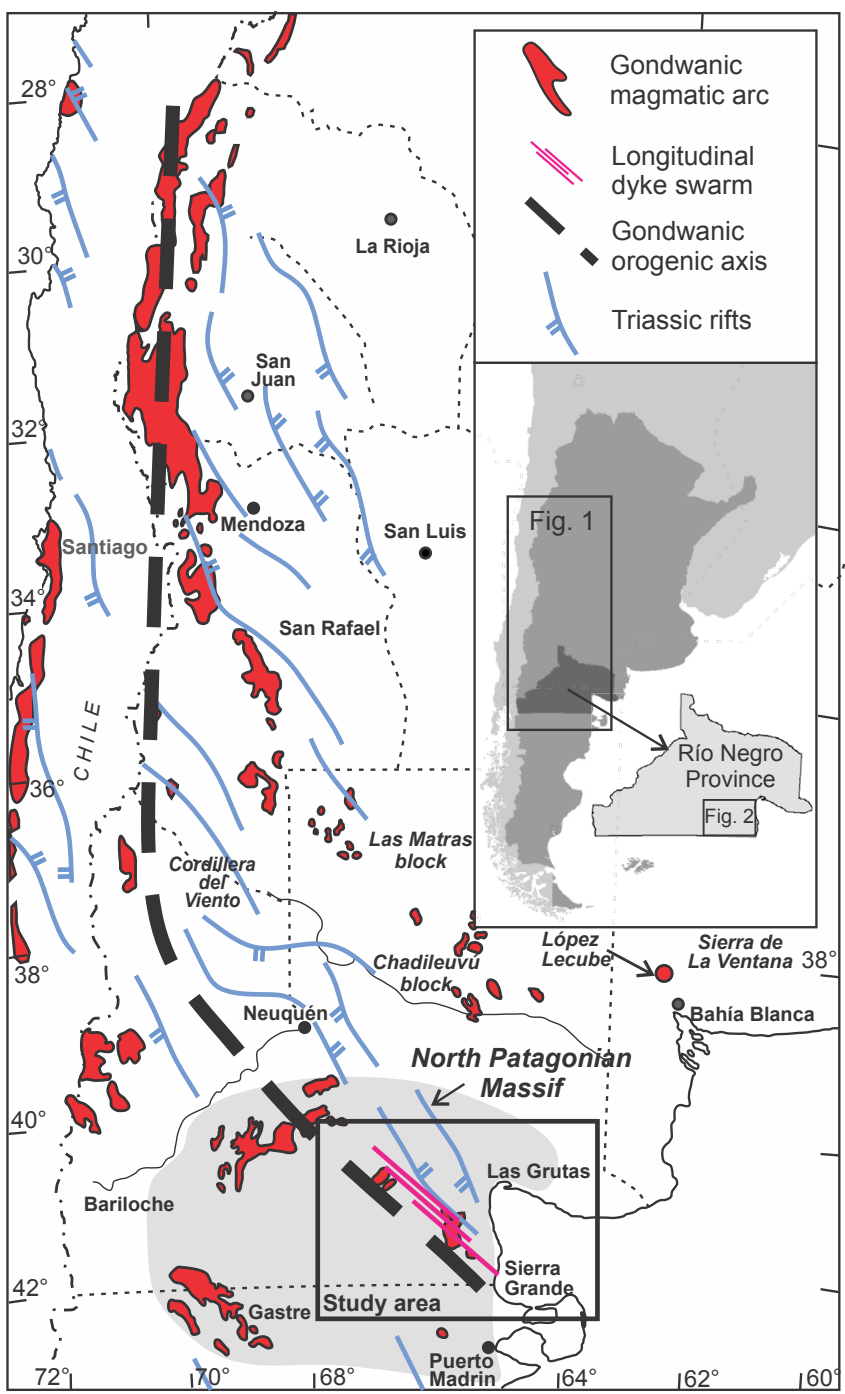

Fig. 1. Gondwanide orogeny and associated magmatism in Argentina and Chile (modified from Llambías and Sato, 2011). The Triassic normal faults of the continental rifts are based on Ramos and Kay (1991).

In the eastern North Patagonian Massif a Middle Triassic dyke swarm was emplaced parallel to the Gondwanide orogenic axis. Because the swarm cut both, the Permian plutonic rocks and the gondwanide deformational structures, it has been considered as postorogenic to the Gondwanide deformation (González et al., 2014). This Triassic magmatism represents the onset of an extensional tectonic regime along the active margin and the inboard region of southwestern Gondwana (González et al., 2014).

In the present contribution, we provide new geochemical data from the dykes of the swarm and interpret them within the geologic and tectonic scheme of the North Patagonian Massif. In order to contribute to regional correlations, we integrate the swarm into the context of the North Patagonian Massif where the Triassic magmatism has been widely recognized (Llambías and Rapela, 1984; Caminos, 2001; Pankhurst et al., 2006).

The new geochemical data in addition to the petrographical characterization (carried out by González et al., 2014) of the dykes permit us to get an insight into the origin and evolution of the earliest Mesozoic magmatism in the eastern North Patagonian Massif.

The geological time scale used in the present contribution corresponds to the GSA Geologic Time Scale v4.0 (http://www. geosociety.org/science/timescale) and the IUGS International Chronostratigraphic Chart v2015/01 (http://www.stratigraphy.org/ index.php/ics-chart-timescale).

\section{Geologic setting}

The study area is located in the eastern part of the North Patagonian Massif, close to Sierra Grande (Fig. 1 and 2). The stratigraphy of the region begins with Cambrian low- and high-grade metamorphic units intruded by Early Ordovician granitoids. A SiluroDevonian silicoclastic sequence overlie the igneous and metamorphic basement rocks. A significant magmatic activity has been registered during Permian when a large number of plutons intruded older rocks. The Triassic dyke swarm, which is the subject of this study, has cut all the Paleozoic sequences. A Jurassic acidic volcanism cover older units.

There is an important development of ductile shear zones related to NE-SW compressive regime (Giacosa, 2001; von Gosen, 2002), which is associated to the NW-SE-trending Permian magmatic arc (Ramos, 1984; Llambías et al., 2002).

\subsection{Basement units and Early Paleozoic sedimentary cover}

The basement units consist of the high-grade Mina Gonzalito Complex, the low-grade El Jagüelito Formation and the Punta Sierra Plutonic Complex (Ramos, 1975; Giacosa, 1987; Busteros et al., 1998; Fig. 2). According to stratigraphic, detrital zircon and archeocyath fossil constraints, the protoliths from the low-grade slates, phyllites and metagraywackes of the El Jagüelito Formation belong to the Cambrian period (Ramos, 1975; Giacosa, 1987; Pankhurst et al., 2006; Naipauer et al., 2010; González et al., 2011). Granitoids belonging to the Early to Middle Ordovician Punta Sierra Plutonic Complex intrude the El Jagüelito Formation after their first tectonometamorphic event (Varela et al., 1998, 2008; von Gosen, 2002; Pankhurst et al., 2006; García et al., 2014a). According to $\mathrm{U}-\mathrm{Pb}$ detrital zircon age constraints on their meta-sedimentary protholiths and a U-Pb zircon magmatic crystallization age of a granodioritic orthogneiss, the protoliths of the high-grade schists, para- and orthogneisses, amphibolites and marbles of the Mina Gonzalito Complex also belong to the Cambrian (Ramos, 1975; Giacosa, 1987; Pankhurst et al., 2006; Greco et al., 2014; Varela et al., 2011). Metamorphic rims on detrital zircons from this unit paragneisses constrain the main metamorphic event to $472 \mathrm{Ma}$ (Pankhurst et al., 2006; Greco et al., 2014).

In Sierra Grande area, the basement rocks are unconformably covered by Siluro-Devonian quartzites of the Sierra Grande Formation and by Cenozoic sediments (Busteros et al., 1998). The sedimentary rocks of Siluro-Devonian cover are affected by major faults, km-scale folds and brittle-ductile microstructures, which are considered of Permian age and part of the Gondwanide deformational history (Japas, 2001; von Gosen, 2002).

\subsection{Late Paleozoic magmatism and ductile shear zones}

The Pailemán Plutonic Complex crystallized during the Permian Period and intruded on both the igneous and metamorphic basement rocks and the sedimentary rocks of the Sierra Grande Formation (Giacosa, 1993; Busteros et al., 1998). The Pailemán Plutonic Complex comprises several plutons, among which the Laguna Medina granodioritic pluton (U-Pb zircon age $291 \pm 5 \mathrm{Ma}$, Varela et al., 2009), Arroyo Pailemán granitic pluton ( $\mathrm{Rb} / \mathrm{Sr}$ whole rock age $268 \pm 3 \mathrm{Ma}$, Grecco et al., 1994), Arroyo Tembrao granodiorite $\left({ }^{39} \mathrm{Ar} /{ }^{40} \mathrm{Ar}\right.$ biotite age $266 \pm 1.5 \mathrm{Ma}$, Grecco and Grégori, 2011) and La Verde granodioritic pluton (U-Pb SHIRMP zircon age $261 \pm 2 \mathrm{Ma}$, García et al., 2014b) should be mentioned. 


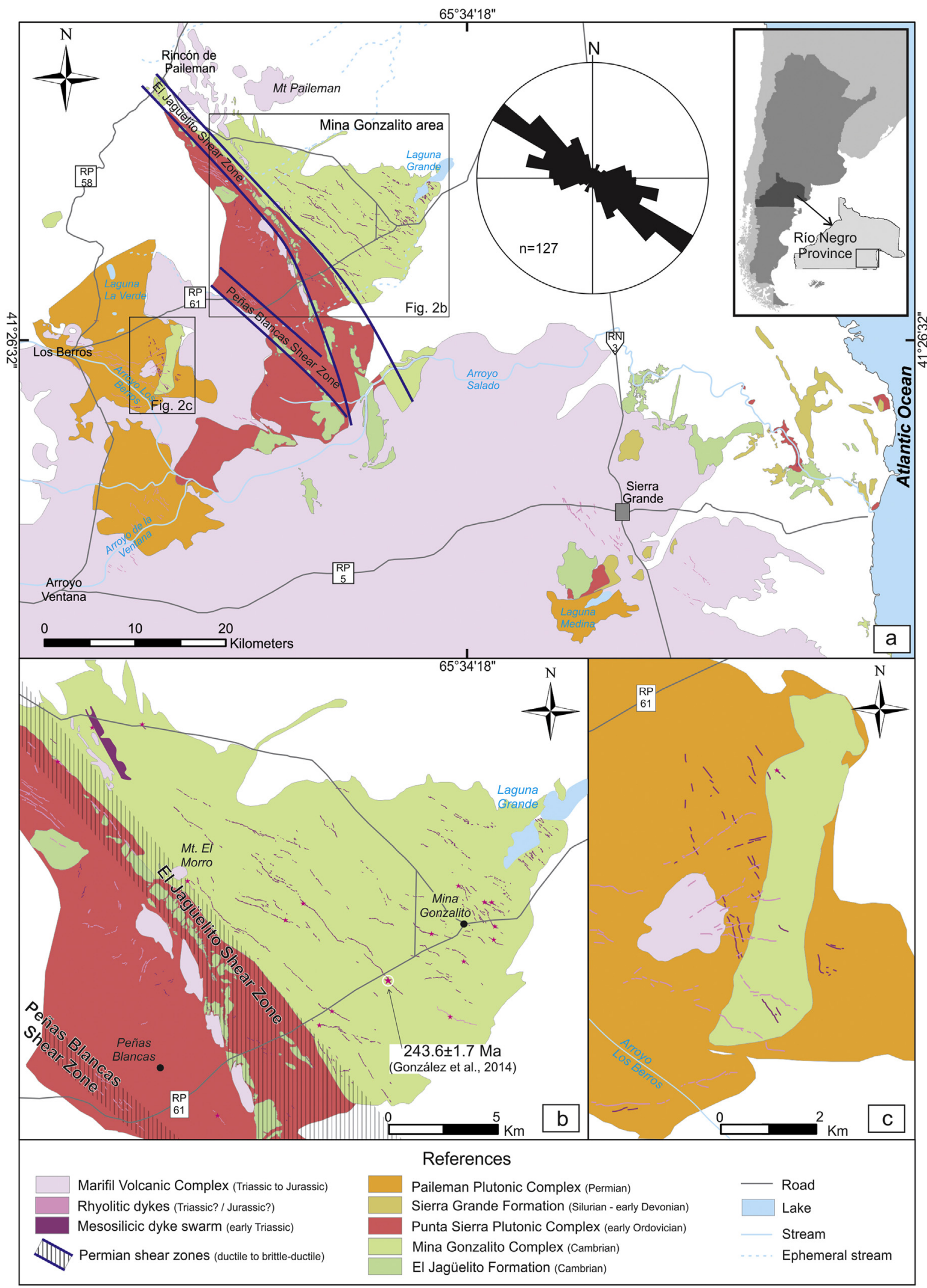

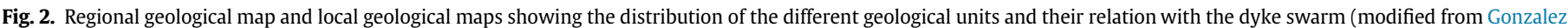

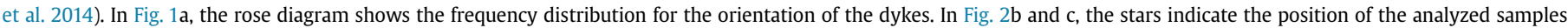
(Table 1).

Petrographic and geochemical features of the Pailemán Plutonic Complex suggest strong affinities with a calcalkaline series related to a magmatic continental arc (Giacosa, 1993, 1994; Grecco et al., 1994; Busteros et al., 1998; García et al., 2014b). 


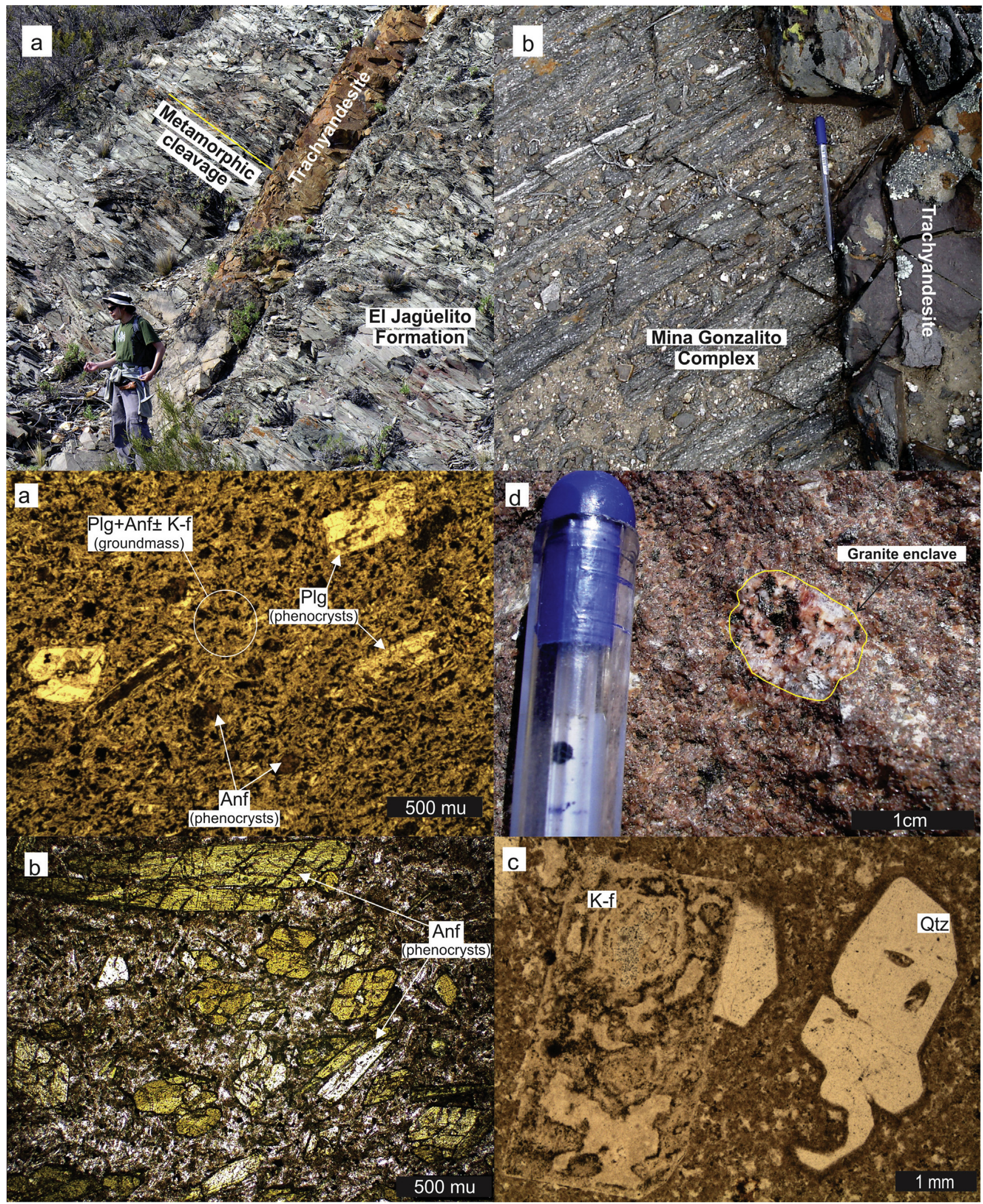

Fig. 3. Field photographs and photomicrographs of the dykes in the swarm showing them relation with the basement rocks and the different textures found. a) A trachyandesitic dyke cutting the ductile structure of the low grade rocks from El Jagüelito Formation. b) A trachyandesitic dyke cutting the ductile structure of a gneiss in Mina Gonzalito area. c field photograph of one granite enclave in a trachyandesitic dyke. Abbreviations: Plg, plagioclase; Anf, amphibole; K-f, K-feldspar or anorthoclase; Qtz, quartz. d) Latite with porphyritic texture characterized by phenocrysts of plagioclase and amphibole set in a groundmass of plagioclase, amphibole and K-feldspar. e) Lamprophyre with porphyritic texture with large phenocrysts of amphibole set in a seriate holocrystalline groundmass of plagioclase and amphibole. f) Rhyolite with phenocrysts of quartz and anorthoclase in a recrystallized felsitic groundmass. Abbreviations: Plg, plagioclase; Anf, amphibole; K-f, K-feldspar or anorthoclase; Qtz, quartz. 
Several ductile to brittle-ductile shear zones cut the Permian plutons and their country rocks and have been proposed as Permian (Giacosa, 2001; von Gosen, 2002). Ductile El Jagüelito and Peñas Blancas shear zones are conspicuous structures that affect the pre-Triassic rocks (Fig. 2a and b). These large shear zones are reactivated as brittle fault zones during the Jurassic (Giacosa, 2001). Furthermore, the Permian granitoids of the Paileman Plutonic Complex are deformed by narrow brittle-to-ductile shear zones (Varela et al., 2009). The describe shear zones are cut by the dykes of the Triassic swarm indicating that they are previous to the Anisian crystallization age of the dykes (as is mentioned in 2.3).

\subsection{The Triassic dyke swarm}

Several andesitic and latitic dykes, with lamprophyric varieties, and minor rhyolites (Ramos, 1975; Vallés, 1978; Giacosa, 1993; González et al., 2014) were gathered in a swarm by González et al. (2008).

The dyke swarm cut the brittle-to-ductile fabrics of all the basement rocks deformed in the Early and Late Paleozoic (Fig. 3a and b; Vallés, 1978; Giacosa, 1993; González et al., 2008). The Permian plutonic rocks (La Verde and Laguna Medina plutons) and the pre-Triassic shear zones are also intruded by the dykes (Fig. 2b and c; Busteros et al., 1998; Giacosa, 2001; von Gosen, 2002; González et al., 2014). The swarm is parallel to the NW-SE orogenic axis of the Permian magmatic arc (Ramos, 1984; Llambías et al., 2002; von Gosen, 2002; González et al., 2014). A crystallization zircon age (U-Pb LA-MC-ICPMS) of $243.6 \pm 1.7$ Ma has been obtained for a latite (trachyandesite) dyke (González et al., 2014). This date suggests that the emplacement and magmatic crystallization of the swarm took place in the Middle Triassic. Hence, this magmatism might be associated with an extensional tectonic after the orogenic Permian compression (González et al., 2014).

\subsection{Jurassic acidic volcanism}

The eruption of the mostly-rhyolitic Marifil Volcanic Complex (Malvicini and Llambías, 1974; Cortés, 1981) occurred during the Jurassic between 188 and 153 Ma (Uliana et al., 1985; Rapela and Pankhurst, 1995; Pankhurst et al., 1998; Féraud et al., 1999; Riley et al., 2001). These volcanic and volaniclastic deposits unconformably cover all older units mentioned above. The Triassic dyke swarm is cutted by rhyolitic dykes assignable to the Marifil Volcanic Complex (Fig. 3b). This unit is composed of rhyolitic lavas and ignimbrites with minor andesites and trachyandesites at the base of the sequence (Busteros et al., 1998).

The basal andesites of the Marifil Volcanic Complex cover an erosive surface above the Permian granitoids (Giacosa, 1993). They also have a composition similar to that of the dykes and are overlain by a volcanic and volcaniclastic acid sequence.

\section{Geology of the dyke swarm}

The dykes were mapped and described by Vallés (1978) and Giacosa (1993), and recently assigned to a NW-SE trending swarm with sub-vertical dip (González et al., 2008; González et al., 2013). The swarm is about $100 \mathrm{~km}$ long and $35 \mathrm{~km}$ wide, between Sierra Grande, near the Atlantic coast, and Rincón de Pailemán, at the foothills of the Somuncura plateau (Figs. 2; González et al., 2014). Further northwest, in the Valcheta-Nahuel Niyeu area, a group of several longitudinal dykes was described by Caminos (2001). They have the same cutting relationships and compositions similar to those of the dykes in Mina Gonzalito-Sierra Grande area. These dykes might be considered as part of NW-SE swarm studied here.

Most of the dykes are continuous tabular shaped or are composed of several separate segments. In a regional distribution, the dykes show parallel to subparallel orientation and, in some cases, an en-échelon arrangement. Tabular dykes display few meters to $20 \mathrm{~km}$ length and few centimeters to $15 \mathrm{~m}$ width. The contact between dykes and country rocks is sharp, mostly straight because of the high rheologic contrast between the country rocks and the dykes during the intrusion (Fig. $3 a$ and $b$ ).

\subsection{Lithological and textural features}

On the basis of mineral associations, the rocks collected from the Mina Gonzalito-Sierra Grande area are classified as andesites, latites, spessartitic lamprophyres and rhyolites (González et al., 2014). The first two are the predominant rocks of the swarm.

The andesites and latites are reddish-brown to yellowish-brown and mostly occur as single intrusions. Dark grey to black lamprophyres appear as occasional composite injections in conjunction with latite dykes. The lamprophyres can also form single intrusions, intersecting the andesitic and latite dykes. The rhyolites are pale pink to dark red and form single dykes.

Another composite intrusion has been found in the Mina Gonzalito area. It is characterized by a dyke with an en-échelon arrangement and separated into two segments: the northwestern part is composed of latite and the southeastern one of orange pinkish rhyolite (Fig. 2b).

As key petrographic features, resulting from a constant modification of the thermal conditions, the majority of the dykes show a well-marked change in texture, ranging from aphanitic texture (sometimes micro-porphyritic) in chilled margins to welldeveloped porphyritic or fine-grained equigranular textures in cores. Seriate texture is also common especially as groundmass in porphyritic sectors.

Flow banded and/or flow laminated structures are present. Several millimetric to decimetric magmatic folds can be locally refolded due to magma flow. In porphyritic texture, euhedral phenocrysts are oriented parallel to flow, and embedded in a groundmass of smaller crystals.

The porphyritic andesite and latite dykes display variably sized phenocrysts of plagioclase and amphibole set in a groundmass of plagioclase and amphibole $\pm \mathrm{K}$-feldspar (Fig. 3c). Apatite, zircon and titanite have been recognized as accessory minerals. No glass has been found. The groundmass of the porphyritic quartz latites have interstitial quartz. The cores of the thicker dykes can also exhibit an agpaitic-like texture. In andesites and latites, glomeroporphyritic clusters of amphibole, plagioclase and apatite are present.

All lamprophyre samples display porphyritic textures typical of these rocks, with large phenocrysts of amphibole set in a seriate holocrystalline groundmass of plagioclase and amphibole (Fig. $3 \mathrm{~d}$ ). Apatite is the most common accessory mineral in these rocks.

The porphyritic texture of the rhyolite is defined by mediumgrained euhedral phenocrysts of quartz, anorthoclase, plagioclase and scarce biotite (Fig. 3e). These phenocrysts are set in a felsitic, very fine-grained groundmass. The embayed quartz phenocrysts contain inclusions of the felsitic groundmass. Perthitic feldspar displays a granophyric arrangement with quartz, while plagioclase is normally zoned and presents sericitized cores and non-altered rims. Apatite and zircon are accessories.

Some of the dykes exhibit weak to moderate alteration, suggesting that solutions might have played an important role in the late-stage of the cooling history. Propylitic alteration has been recognized in andesites, trachyandesites and lamprophyres. Magmatic minerals have been pseudomorphically replaced by chlorite, calcite, epidote and titanite. Additionally, propylitization results in miarolitic cavities filled with the alteration mineral 
assemblage. On the other hand, the rhyolites show an adulariasericite alteration of feldspars and silicification patches in their groundmass. These secondary mineral associations can even respond either to a deuteric alteration caused by late magmatic fluids or to a posterior hydrothermal fluids circulation.

Another feature of these rocks is the presence of enclaves of the early Paleozoic low-grade and high-grade metamorphic country rocks and the Permian granitoids (Fig. 3f). These are variably sized pieces (from micrometers to decimeters) incorporated into the dykes during intrusion. The inclusions are usually affected by contact metamorphism, in which heat and fluids cause mineralogic and chemical changes, especially at the margins (González et al., 2014).

\section{Geochemical features}

\subsection{Methodology}

The present study is based on 19 samples collected from the different varieties of rocks the dyke swarm (13 samples of latites, 4 samples of rhyolites and 2 samples of lamprophyres). Major and trace element concentrations were determined in $0.2 \mathrm{~g}$ of powder from samples which were prepared by alkaline fusion with lithium borate, diluted with acid digestion and analyzed in ICP-MS at ACME
Analytical Laboratories S.A.

The analytical results are shown in Table 1, which also includes the analysis of one sample published by Giacosa (1993) for a trachyandesitic dyke crosscutting the La Verde Pluton (oxides are recalculated to volatile-free totals of $100 \%$ ).

\subsection{Results and characterization}

\subsubsection{Classification}

The wide mineral variation of the dykes, determined by petrographic analyses has also been corroborated by their heterogeneous geochemical composition. In the Total Alkalis Silica diagram (TAS) of Le Maitre (2002), the rocks plot mostly between trachyandesite and trachyte fields. The $\mathrm{SiO}_{2}$ content ranges from 56 to $67 \%$ and the alkalis content $\left(\mathrm{Na}_{2} \mathrm{O}+\mathrm{K}_{2} \mathrm{O}\right)$ varies between 7.7 and $9.7 \%$, following a continuous trend, which is transitional between sub-alkaline and alkaline series (Fig. 4a). This tendency is characteristic of mildly-alkaline series (Parat et al., 2005). The two analyzed lamprophyres plot in the field of trachyandesites along the same trend, with $\mathrm{SiO}_{2}$ around $60 \%$ wt and alkalis ranging between 6.97 and $7.57 \%$.

A sample of a fine grained, virtually aphyric latite plots as a basaltic trachyandesite $\left(52 \% \mathrm{SiO}_{2}\right.$, and $5.4 \%$ alkalis $)$, far from the general characteristics of the other samples. However, the trace

Table 1

Geochemical analysis results for mayor and trace elements of the samples from the dykes. The sample CVM 128 correspond to Giacosa (1993).

\begin{tabular}{|c|c|c|c|c|c|c|c|c|c|c|c|c|c|c|c|c|c|c|c|c|c|c|}
\hline & & \multirow{2}{*}{$\begin{array}{l}\text { Detection } \\
\text { Limit }\end{array}$} & \multicolumn{16}{|c|}{ Trachyandesites } & \multicolumn{4}{|c|}{ Rhyolites } \\
\hline & & & $\begin{array}{l}\text { SG } \\
34\end{array}$ & LL18 & GNZ008 & $\begin{array}{l}\text { GNZ } \\
53 \mathrm{~A}\end{array}$ & $\begin{array}{l}\text { GNZ } \\
53 \mathrm{~B}\end{array}$ & $\begin{array}{l}\text { GNZ } \\
01\end{array}$ & $\begin{array}{l}\text { GNZ } \\
02\end{array}$ & $\begin{array}{l}\text { GNZ } \\
07\end{array}$ & GNZ201208 & $\begin{array}{l}\text { GNZ } \\
10\end{array}$ & $\begin{array}{l}\text { GNZ } \\
14\end{array}$ & $\begin{array}{l}\text { GNZ } \\
17\end{array}$ & $\begin{array}{l}\text { GNZ } \\
18\end{array}$ & $\begin{array}{l}\text { GNZ } \\
19\end{array}$ & $\begin{array}{l}\text { GNZ } \\
21\end{array}$ & $\begin{array}{l}\text { CVM } \\
218\end{array}$ & $\begin{array}{l}\text { GNZ } \\
03\end{array}$ & $\begin{array}{l}\mathrm{ZCJ} \\
17\end{array}$ & $\begin{array}{l}\text { GNZ } \\
122\end{array}$ & $\begin{array}{l}\text { GNZ } \\
25\end{array}$ \\
\hline $\mathrm{SiO}_{2}$ & $\%$ & 0.01 & 63.79 & 59.07 & 58.33 & 64.8 & 60.24 & 52.17 & 60.01 & 52.6 & 57.33 & 48.67 & 63.6 & 64.63 & 64.35 & 55.34 & 57.71 & 64.69 & 69.11 & 81.89 & 76.88 & 71.86 \\
\hline $\mathrm{Al}_{2} \mathrm{O}_{3}$ & $\%$ & 0.01 & 16.82 & 15.63 & 15.93 & 14.91 & 14.63 & 15.24 & 16.06 & 15.57 & 15.76 & 13.79 & 16.92 & 17.12 & 15.17 & 13.7 & 15.68 & 16.9 & 13.73 & 8.88 & 12.06 & 13.47 \\
\hline $\mathrm{Fe}_{2} \mathrm{O}_{3}$ & $\%$ & 0.04 & 3.29 & 6.38 & 5.58 & 2.8 & 5.46 & 6.65 & 4.52 & 6.99 & 5.96 & 8.21 & 3.22 & 3.2 & 3.14 & 5.87 & 6.61 & 4.09 & 2.21 & 0.29 & 0.82 & 1.74 \\
\hline $\mathrm{MgO}$ & $\%$ & 0.01 & 0.91 & 4.14 & 4.54 & 2.19 & 4.2 & 4.5 & 1.77 & 3.96 & 4.76 & 7.88 & 0.96 & 1.04 & 2.38 & 6.2 & 3.03 & 0.96 & 0.56 & 0.04 & 0.29 & 0.4 \\
\hline $\mathrm{CaO}$ & $\%$ & 0.01 & 2.75 & 4.47 & 4.58 & 1.99 & 3.85 & 5.35 & 3.53 & 4.97 & 4.63 & 7.73 & 2.43 & 1.44 & 2.64 & 5.27 & 4.66 & 2.71 & 2.61 & 0.24 & 0.12 & 0.29 \\
\hline $\mathrm{Na}_{2} \mathrm{O}$ & $\%$ & 0.01 & 4.86 & 3.45 & 4.1 & 4.31 & 3.97 & 3.08 & 3.94 & 4.24 & 3.97 & 3.48 & 5.32 & 5.52 & 4.58 & 3.47 & 3.37 & 4.89 & 2.93 & 0.14 & 0.09 & 0.22 \\
\hline $\mathrm{K}_{2} \mathrm{O}$ & $\%$ & 0.01 & 3.81 & 3.35 & 3.27 & 4.56 & 3.93 & 4.04 & 4.29 & 3.29 & 3.52 & 1.55 & 3.89 & 3.84 & 3.95 & 3.48 & 3.61 & 3.66 & 4.78 & 7.23 & 7.44 & 9.49 \\
\hline $\mathrm{TiO}_{2}$ & $\%$ & 0.01 & 0.603 & 0.77 & 0.71 & 0.46 & 0.76 & 1.05 & 0.74 & 1.08 & 0.78 & 1.2 & 0.58 & 0.6 & 0.49 & 0.66 & 1.1 & 0.59 & 0.38 & 0.06 & 0.13 & 0.33 \\
\hline $\mathrm{P}_{2} \mathrm{O}_{5}$ & $\%$ & 0.01 & 0.3 & 0.22 & 0.23 & 0.33 & 0.34 & 0.43 & 0.36 & 0.41 & 0.27 & 0.58 & 0.29 & 0.28 & 0.18 & 0.32 & 0.55 & 0.35 & 0.18 & 0.001 & 0.04 & 0.07 \\
\hline $\mathrm{MnO}$ & $\%$ & 0.01 & 0.041 & 0.1 & 0.08 & 0.04 & 0.09 & 0.1 & 0.06 & 0.11 & 0.09 & 0.13 & 0.04 & 0.05 & 0.04 & 0.1 & 0.1 & 0.11 & 0.11 & 0.001 & 0.03 & 0.02 \\
\hline $\mathrm{Cr}_{2} \mathrm{O}_{3}$ & $\%$ & 0.002 & 0.002 & 0.021 & 0.023 & 0.011 & 0.026 & 0.017 & 0.005 & 0.007 & 0.022 & 0.067 & 0.011 & 0.001 & 0.013 & 0.046 & 0.007 & & 0.005 & 0.007 & 0.001 & 0.003 \\
\hline $\mathrm{Ni}$ & $\mathrm{ppm}$ & 20 & 20 & 39 & 101 & 31 & 54 & 76 & 19 & 19 & 79 & 143 & 19 & 19 & 58 & 117 & 28 & & 39 & 19 & 19 & 19 \\
\hline Sc & ppm & 1 & 3 & 16 & 12 & 6 & 13 & 12 & 5 & 15 & 13 & 21 & 3 & 3 & 7 & 15 & 14 & & 4 & 2 & 3 & 5 \\
\hline LOI & $\%$ & -5.1 & 3.15 & 2 & 2.2 & 3.3 & 2.1 & 6.9 & 4.3 & 6.5 & 2.5 & 6.3 & 2.4 & 2 & 2.8 & 5.2 & 3.1 & 1.67 & 3.1 & 1.2 & 1.9 & 1.8 \\
\hline Sum & $\%$ & & 100.3 & 99.61 & 99.59 & 99.66 & 99.61 & 99.57 & 99.57 & 99.71 & 99.56 & 99.62 & 99.71 & 99.7 & 99.7 & 99.7 & 99.49 & 100.62 & 99.75 & 99.93 & 99.78 & 99.73 \\
\hline $\mathrm{Ba}$ & ppm & 1 & 1594 & 1017 & 985 & 1328 & 1313 & 1214 & 1552 & 1106 & 892 & 649 & 1102 & 1376 & 1082 & 899 & 1817 & & 866 & 173 & 498 & 1204 \\
\hline Cs & ppm & 0.1 & 3.3 & 13.4 & 2.2 & 2.1 & 2.6 & 1.9 & 2.9 & 2.2 & 4.2 & 3.8 & 3.2 & 2 & 3.2 & 2.7 & 4.1 & & 8.4 & 4.3 & 17.8 & 9.1 \\
\hline $\mathrm{Hf}$ & ppm & 0.1 & 6 & 5.4 & 4.6 & 4.8 & 4.7 & 5.4 & 6.4 & 5.2 & 4.4 & 5.4 & 5.9 & 6 & 4.7 & 4.2 & 6.9 & & 4.7 & 2.4 & 4.1 & 6.8 \\
\hline $\mathrm{Nb}$ & ppm & 0.1 & 13 & 9.5 & 7.6 & 7.6 & 15.5 & 9.4 & 11.2 & 8.1 & 7.4 & 20.6 & 10.2 & 10.5 & 6.7 & 6.1 & 15.9 & & 12.1 & 20.2 & 24.7 & 24.5 \\
\hline $\mathrm{Rb}$ & ppm & 0.1 & 132 & 133.2 & 113.5 & 152.5 & 137 & 95.3 & 133.4 & 109.1 & 122.7 & 41.7 & 118.8 & 106.9 & 127.9 & 120.8 & 94.7 & & 251.6 & 422.2 & 487.7 & 429.5 \\
\hline $\mathrm{Sr}$ & $\mathrm{ppm}$ & 0.5 & 574 & 590.7 & 882 & 373.9 & 1006.5 & 617.7 & 490.1 & 446.8 & 777.8 & 623.2 & 698.1 & 783.9 & 626.1 & 438.7 & 864.1 & & 204 & 74 & 45.1 & 53.4 \\
\hline Ta & ppm & 0.1 & 1.2 & 1.1 & 0.8 & 0.9 & 1.2 & 0.6 & 0.9 & 0.5 & 0.8 & 1 & 1 & 1.2 & 0.9 & 0.6 & 0.8 & & 1.8 & 4.3 & 3.3 & 3.2 \\
\hline Th & ppm & 0.2 & 7.7 & 11.3 & 9 & 8.3 & 13.1 & 11.1 & 10.8 & 6 & 7.9 & 13.1 & 7.4 & 7.4 & 12.5 & 8 & 10.3 & & 18.6 & 22.3 & 27.8 & 29.6 \\
\hline $\mathrm{U}$ & ppm & 0.1 & & 1.8 & 1.9 & 2.1 & 3.4 & 1.6 & 2.3 & 1.4 & 1.7 & 2.4 & 1.5 & 1.7 & 3.1 & 1.6 & 2.7 & & 3.1 & 2.9 & 5.7 & 5.1 \\
\hline $\mathrm{Zr}$ & ppm & 0.1 & 229 & 199.2 & 181.8 & 157.2 & 189.9 & 200.9 & 264.9 & 186.4 & 164.1 & 225.8 & 239 & 242.6 & 165.8 & 131.3 & 244.8 & & 167.9 & 45.4 & 81.4 & 223.6 \\
\hline $\mathrm{Y}$ & ppm & 0.1 & 7 & 19.6 & 12.1 & 9.8 & 19.6 & 14.1 & 12.8 & 17.5 & 12.6 & 20.3 & 6.5 & 7.4 & 10.3 & 13.8 & 24.3 & & 13.8 & 10.1 & 15.2 & 27.4 \\
\hline La & ppm & 0.1 & 34.1 & 43.1 & 32.6 & 25 & 38.3 & 48.1 & 40.5 & 31.7 & 30.3 & 41.6 & 35.4 & 36.3 & 34.1 & 27.5 & 53.1 & & 40.8 & 13.7 & 26.4 & 57.4 \\
\hline $\mathrm{Ce}$ & ppm & 0.1 & 72.1 & 84.3 & 66.5 & 51.3 & 76.2 & 95.1 & 79.6 & 66.6 & 62 & 87.4 & 72.1 & 75 & 66.9 & 55.6 & 100.7 & & 79.6 & 26.3 & 49.2 & 123.5 \\
\hline $\operatorname{Pr}$ & $\mathrm{ppm}$ & 0.02 & 8.64 & 9.73 & 7.61 & 6.17 & 8.87 & 10.96 & 9.29 & 8.01 & 7.14 & 10.22 & 8.64 & 8.67 & 7.42 & 6.54 & 12.05 & & 8.95 & 2.42 & 4.84 & 12.07 \\
\hline $\mathrm{Nd}$ & ppm & 0.3 & 34.4 & 37.8 & 31.2 & 24.2 & 33.4 & 41.8 & 35.2 & 32.8 & 28.6 & 42.3 & 31.3 & 36.2 & 29.5 & 29.5 & 48.9 & & 35 & 6.7 & 13.8 & 42.4 \\
\hline $\mathrm{Sm}$ & ppm & 0.05 & 6.1 & 6.59 & 5.29 & 4.38 & 6.06 & 7.14 & 6.53 & 6.32 & 5.18 & 7.28 & 5.34 & 5.58 & 5.12 & 4.65 & 7.75 & & 5.45 & 1.03 & 2.37 & 6.75 \\
\hline $\mathrm{Eu}$ & $\mathrm{ppm}$ & 0.02 & 1.43 & 1.41 & 1.3 & 1.11 & 1.49 & 1.82 & 1.99 & 1.71 & 1.25 & 1.84 & 1.29 & 1.36 & 1.16 & 1.15 & 2.04 & & 1.13 & 0.08 & 0.36 & 0.96 \\
\hline Gd & ppm & 0.05 & 4 & 4.79 & 3.95 & 3.32 & 5.1 & 5.18 & 4.78 & 5.04 & 3.85 & 5.77 & 3.83 & 3.95 & 3.58 & 3.59 & 6 & & 3.99 & 0.96 & 1.86 & 5.04 \\
\hline $\mathrm{Tb}$ & ppm & 0.01 & 0.4 & 0.71 & 0.52 & 0.42 & 0.71 & 0.69 & 0.6 & 0.69 & 0.51 & 0.8 & 0.43 & 0.42 & 0.44 & 0.49 & 0.84 & & 0.52 & 0.18 & 0.31 & 0.78 \\
\hline Dy & ppm & 0.05 & 1.9 & 4.14 & 2.5 & 1.89 & 3.96 & 3.09 & 2.65 & 3.5 & 2.42 & 4.31 & 1.68 & 1.72 & 2.12 & 2.41 & 4.87 & & 2.34 & 1.15 & 1.9 & 4.68 \\
\hline Ho & ppm & 0.02 & 0.3 & 0.71 & 0.44 & 0.36 & 0.73 & 0.56 & 0.41 & 0.66 & 0.49 & 0.75 & 0.26 & 0.22 & 0.4 & 0.55 & 0.87 & & 0.45 & 0.26 & 0.47 & 0.98 \\
\hline $\mathrm{Er}$ & ppm & 0.03 & 0.7 & 2.2 & 1.26 & 0.89 & 2.25 & 1.33 & 1.22 & 1.71 & 1.31 & 2.05 & 0.48 & 0.59 & 1.21 & 1.4 & 2.24 & & 1.32 & 1.13 & 1.57 & 2.93 \\
\hline $\mathrm{Tm}$ & ppm & 0.01 & 0.08 & 0.28 & 0.18 & 0.12 & 0.31 & 0.18 & 0.16 & 0.25 & 0.19 & 0.28 & 0.07 & 0.06 & 0.15 & 0.21 & 0.36 & & 0.18 & 0.19 & 0.3 & 0.5 \\
\hline $\mathrm{Yb}$ & $\mathrm{ppm}$ & 0.05 & 0.5 & 1.94 & 1.13 & 0.88 & 1.97 & 1.16 & 1.08 & 1.62 & 1.15 & 1.94 & 0.5 & 0.43 & 0.99 & 1.5 & 2.17 & & 1.16 & 1.61 & 2.32 & 3.28 \\
\hline Lu & $\mathrm{ppm}$ & 0.01 & 0.07 & 0.27 & 0.16 & 0.12 & 0.31 & 0.15 & 0.16 & 0.25 & 0.17 & 0.25 & 0.06 & 0.05 & 0.15 & 0.19 & 0.33 & & 0.17 & 0.26 & 0.33 & 0.51 \\
\hline
\end{tabular}



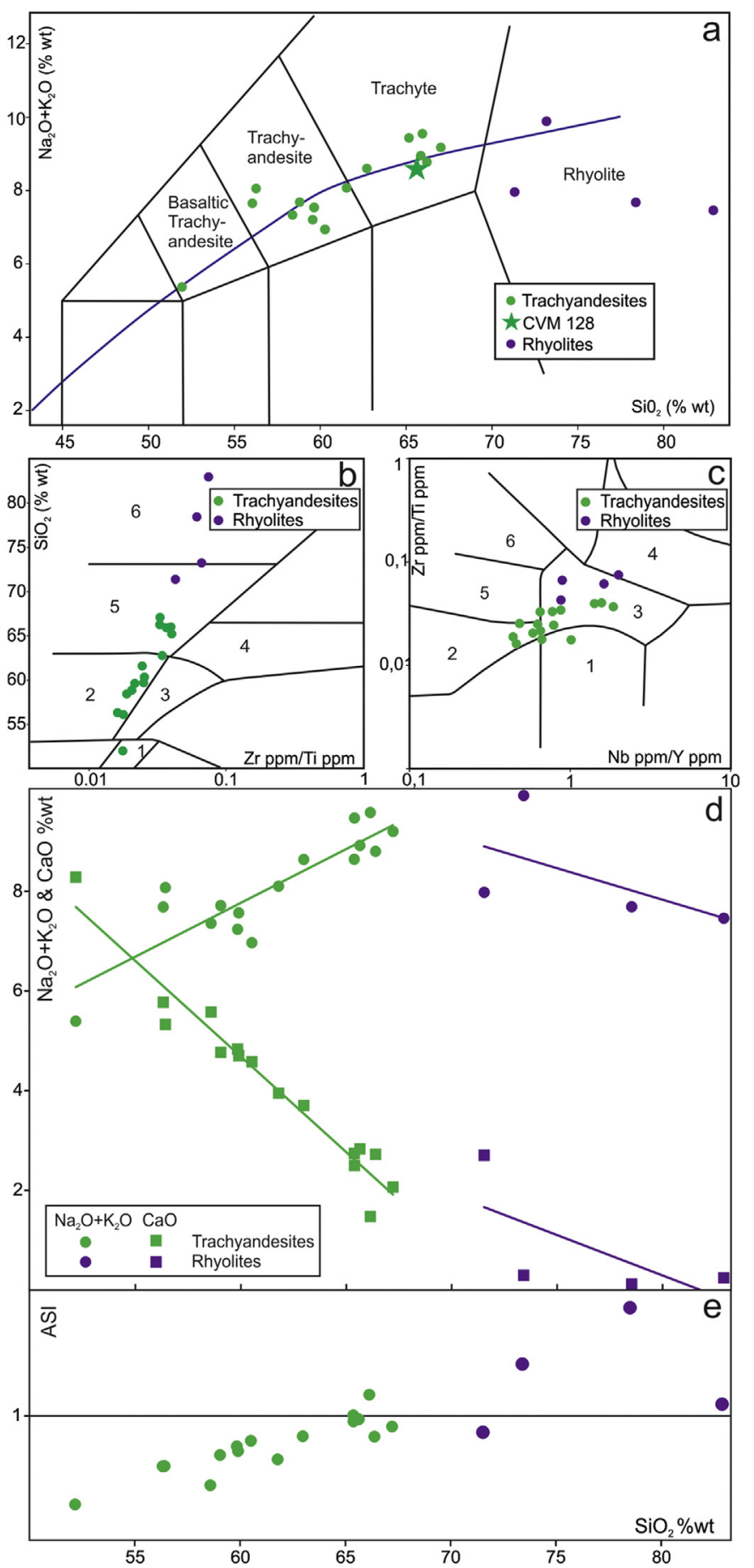

Fig. 4. Geochemical diagrams used to classify and characterize the dykes; a) TAS diagram (Le Maitre 2002); b) Zr/Ti versus SiO2 diagram (Winchester and Floyd, 1977); c) $\mathrm{Nb} / \mathrm{Y}$ versus $\mathrm{Zr} / \mathrm{Ti}$ (Winchester and Floyd, 1977). CVM 128 correspond to a sample from Giacosa (1993). d) Peacock (1931) index showing the trend lines of the two group of samples; the group of trachyandesites have the intersection in $51.94 \%$ of $\mathrm{SiO}_{2} \%$ meanwhile the rhyolites have subparallel trends of $\mathrm{CaO}$ and $\mathrm{Na}_{2} \mathrm{O}+\mathrm{K}_{2} \mathrm{O}$. e) Shand's (1943) alumina saturation molar ratio versus $\mathrm{SiO}_{2} \%$ plot; the samples vary from metaluminous to peraluminous. ASI (molar) $=\mathrm{Al}_{2} \mathrm{O}_{3} /\left(\mathrm{Na}_{2} \mathrm{O}+\mathrm{K}_{2} \mathrm{O}+\mathrm{CaO}\right)$. References for fields in figures b) and c): 1 - Alkali Basalt, 2 - Andesite, 3 - Trachyandesite, 4 Trachyte, 5 - Dacite and Rhyodacite, 6 - Rhyolite.

elements and Rare Earth Elements (REE) features suggest that it is part of the same magmatic trend.

The rhyolites plot as sub-alkaline rhyolites with more than $72 \%$ of $\mathrm{SiO}_{2}$ and $\mathrm{Na}_{2} \mathrm{O}+\mathrm{K}_{2} \mathrm{O} / \mathrm{Al}_{2} \mathrm{O}_{3}$ lower than 1 . They do not show a clear continuity with the mesosilisic trend. Their trace elements and REE features are also different from the trachyandesitic group.

Our petrographic studies indicate that some of the samples are slightly altered. A different classification method should be used in order to establish the importance of element remobilization as a product of alteration and how it might affect the rock classification. The problem of element mobility during alteration processes may be minimized by considering the high field strength incompatible elements (i.e., Ti, Zr, P, Nb, Y and REE) that are considered relatively immobile during alteration and low-grade metamorphism (Pearce and Cann, 1973; Pearce, 1982). Winchester and Floyd (1977) used immobile trace elements and their ratios for the classification of igneous rocks and also to discriminate between different magma series. The $\mathrm{Zr} / \mathrm{Ti}$ ratio and $\mathrm{SiO}_{2} \%$ (Fig. $4 \mathrm{~b}$ ) serve as an index of fractionation and the $\mathrm{Nb} / \mathrm{Y}$ ratio serves as an index of alkalinity. In the $\mathrm{Zr} / \mathrm{Ti}$ vs $\mathrm{Nb} / \mathrm{Y}$ diagram (Fig. 4c), the samples plot in the alkali basalt, andesite, trachyandesite, and trachyte fields. In the $\mathrm{Zr} / \mathrm{Ti}$ vs $\mathrm{SiO}_{2} \%$ diagram, however, the samples plot in the fields of alkali basalt, andesite, rhyodacite/dacite and rhyolite. Both diagrams confirm the TAS classification and the slightly alkaline affinity observed in it.

\subsubsection{Major and trace element characteristics}

The $\mathrm{MgO} /(\mathrm{MgO}+\mathrm{FeO})$ molar ratios $(\mathrm{Mg \#})$ for the dykes decrease gradually from basaltic trachyandesite to trachyte to the most evolved rhyolite samples $(0.49,0.40$ and 0.24 , on average respectively). The $\mathrm{Na}_{2} \mathrm{O}$ content is generally higher than $\mathrm{K}_{2} \mathrm{O}$ in the mesosilisic rocks. On the contrast, the rhyolites have a $\mathrm{K}_{2} \mathrm{O}$ content greater than $\mathrm{Na}_{2} \mathrm{O}$.

The Harker's diagrams of major elements exhibit a linear trend between the basaltic trachyandesites and trachytes, which might be interpreted as the effect of fractional crystallization (Fig. 5). The rhyolites show a similar picture but with a different slope in the trend line. The $\mathrm{K}_{2} \mathrm{O}$ vs $\mathrm{SiO}_{2}$ diagram shows that the samples are part of the high-K, calcalkaline series (Fig. 7; Le Maitre, 2002). The Peacock's index (1931), obtained for the mesosilicic samples, is 51.94 and indicates that the rocks belong to the alkali-calcic suite (Fig. 4d).

Shand's alumina saturation molar ratio (1943) ranges between 0.64 and 1.08 , indicating that most of the trachyandesites are metaluminous (Fig. 4e). The rhyolites are peraluminous with ASI $>1.05$.

Incompatible element variation patterns for the trachyandesitic and rhyolitic dykes are shown in Fig. 6a (normalized to the N-MORB after Pearce, 1982). In every case the mesosilicic dykes show an inclined pattern (i.e., enrichment in Large-Ion Lithophile Elements -LILE- relative to High Field Strength Elements -HFSE-) and are characterized by negative $\mathrm{Ta}, \mathrm{Nb}, \mathrm{P}, \mathrm{Zr}$ and $\mathrm{Ti}$ anomalies. They also exhibit a relative enrichment in $\mathrm{Ba}, \mathrm{Rb}$ and $\mathrm{K}$. An extreme depletion in $\mathrm{P}$ and $\mathrm{Ti}$ and negative $\mathrm{Ba}$ and $\mathrm{Sr}$ anomalies separate the rhyolitic samples from the trachyandesitic ones (Fig. $6 \mathrm{a})$. The $(\mathrm{Rb} / \mathrm{Yb})_{\mathrm{N}}$ ratio is high and ranges between 36.64 and 448.8 .

The spessartitic lamprophyres share the same geochemical features and incompatible element variation patterns as those of trachyandesites and trachytes (Figs. 4-8). The lamprophyres appear as part of the same mildly-alkaline trend already distinguished by major element characterization. According to all these geochemical features, they might belong to the group of calcalkaline lamprophyres (after Rock, 1987), which have a very close spatial, temporal and chemical relation with high-K, calcalkaline postorogenic rocks in continental magmatic arcs (Pearce, 1982, 1983; Thompson et al., 1984; Parat et al., 2005).

The rhyolites are geochemically slightly dissimilar to the trachyandesitic samples. They have higher $\mathrm{SiO}_{2} \%$ and $\mathrm{K}_{2} \mathrm{O} \%$ content, are clearly peraluminous and their $\mathrm{Mg \#}$ is lower. Although the 


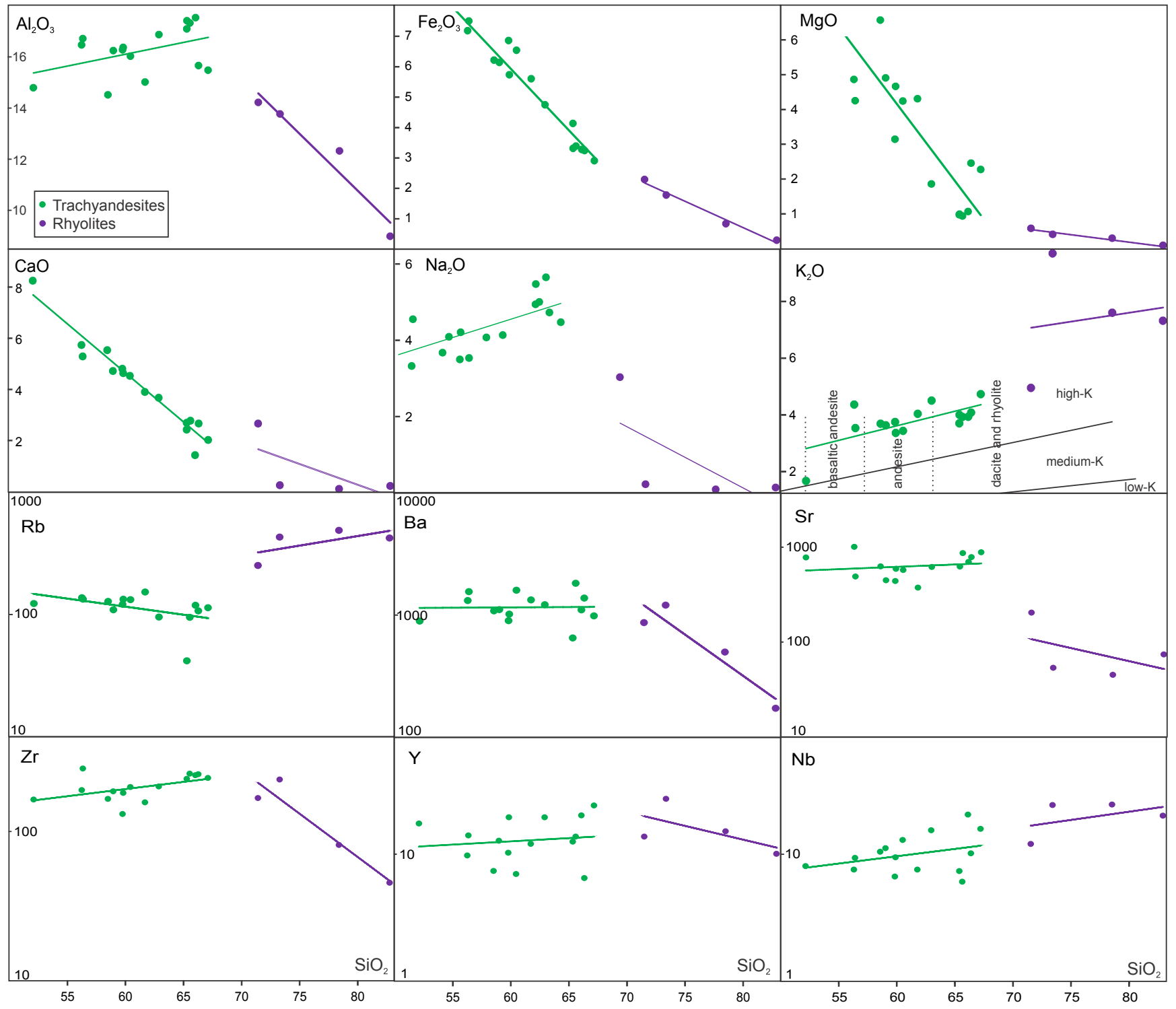

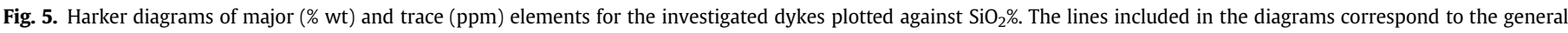
trend of each group of rocks calculated using the linear correlation of the values. The $\mathrm{K}_{2} \mathrm{O}$ vs. $\mathrm{SiO}_{2}$ diagram includes the classification of Le Maitre (2002).

incompatible element patterns (spider diagrams) of the rhyolites are similar to the trachyandesitic samples, the positive and negative anomalies are sharper. Furthermore the rhyolites show negative anomalies of $\mathrm{Sr}$ and Ba (Fig. 6a).

\subsubsection{Rare earth element patterns}

The concentrations of the REE are shown in Table 1 and are illustrated in the chondrite-normalized REE diagrams (Fig. 6b). The REE distribution diagrams show an inclined pattern caused by a high Light REE content and a lower High REE content (Fig. 6b; chondrite normalized after Sun and McDonough, 1989). The trachyandesites exhibit a small negative Eu anomaly $\left(\mathrm{Eu} / \mathrm{Eu}^{*}=0.73-\right.$ 1.04) while the rhyolites display a strong negative one (Eu/ $\left.\mathrm{Eu}^{*}=0.24-0.71\right)$. These REE patterns are characteristic of less evolved rocks from calcalkaline magmas (Gill, 2010).

The trachyandesitic samples are characterized by inclined nostepped patterns $\left(\mathrm{La} / \mathrm{Lu}_{\mathrm{N}}=13.24-77.81\right)$ together with a relatively fractionated HREE segment $\left(\mathrm{Gd} / \mathrm{Lu}_{\mathrm{N}}=2.03-9.76\right)$ and practically no-fractionated LREE patterns $\left(\mathrm{La} / \mathrm{Sm}_{\mathrm{N}}=3.24-4.42\right)$.

Slightly lower content of REE than the mesosilicic samples are shown in the rhyolitic ones. Their REE patterns are stepped (La/ $\mathrm{Lu}_{\mathrm{N}}=5.65-25.72$ ) and they display relative unfractionated HREE $\left(\mathrm{Gd} / \mathrm{Lu}_{\mathrm{N}}=0.46-2.9\right)$ and high LREE fractionated patterns (La/ $\left.\mathrm{Sm}_{\mathrm{N}}=4.83-8.59\right)$.

\section{Discussion}

There are many examples of dyke swarms hosted by a magmatic arc with a close spatial, temporal and genetic relationship with it (Llambías and Sato, 1990; Chen and Moore, 1979; Coleman et al., 1994; Carracedo et al., 1997; Teixeira et al., 2002; El-Sayed, 2006; Zhang and Zou, 2012). In general, these swarms show transitional geochemical features between subduction-related magmatic arc and collisional or continental within-plate settings. They are complex suites of rocks that can exhibit either a strong bimodality or a complete series between two end-members. This late to postorogenic magmatism is linked to a geotectonic process that takes place at subduction margins. There, a thermal anomaly affects the continental lithosphere and leads to the production of partial melts. Additionally, dyke swarms are linked to the extensional process 
that deforms and modifies the tectonic configuration of the lithosphere.

In the following sections we discuss the genetic implications of the new geochemical data from the swarm as well as its correlation with others Triassic magmatic units in the North Patagonian Massif. This Early Mesozoic magmatism might has a significant role during the first stages of the Pangea break-up as evidence of changes in tectonic regimen and as indicators of geotectonic process.

\subsection{Petrogenesis}

There are two chemically separated groups of rocks in the studied dyke swarm. Although all dykes appear to belong to the same NW structural system, the geochemical differences between trachyandesitic and rhyolitic dykes are remarkable.

The differences in composition might be due to the following causes: 1) the existence of different sources, 2) chemical and mineralogical heterogeneities in the source, 3) different degrees in the partial melting of the source/sources, and 4) magma composition modifications by fractional crystallization and/or crustal contamination processes.

Following this idea, we are treating the rhyolites separately from the trachyandesitic (mesosilicic) rocks of the dyke swarm.

\subsubsection{Trachyandesitic dykes}

The immobile element ratios (i.e. $\mathrm{Zr} / \mathrm{Ti}, \mathrm{Zr} / \mathrm{Y}$ and $\mathrm{Zr} / \mathrm{Nb}$ ) are useful to evaluate the roles that fractional crystallization, partial melting, and source heterogeneity play in magma compositional variations (Pearce and Norry, 1979; Pearce, 1980; Saunders et al., 1980). These elements are not fractionated during the origin of magmas and do not change significantly during their generation and evolution.

The $\mathrm{Zr} / \mathrm{Y}$ and $\mathrm{Zr} / \mathrm{Ti}$ ratios show a positive linear progression with $\mathrm{SiO}_{2}$ (Fig. $4 \mathrm{~b}$ and $6 \mathrm{c}$ ). Whereas the $\mathrm{Zr} / \mathrm{Nb}$ ratio shows a negative linear progression with $\mathrm{SiO}_{2}$. Nevertheless, the $\mathrm{Zr} / \mathrm{Y}$ and $\mathrm{Zr} / \mathrm{Nb}$ ratios show a scattered distribution different to the $\mathrm{Zr} / \mathrm{Ti}$ ratio. A heterogeneity in the source or progressive melting variations are suggested by the differences in the $\mathrm{Zr} / \mathrm{Y}$ ratio.

The high $(\mathrm{La} / \mathrm{Lu})_{\mathrm{N}}$ ratio between 13.24 and 77.81 (29.13 in average) suggests a peridotitic garnet-bearing source for the trachyandesites (Gill, 2010).

The enrichment in LILE and Light REE, the high $\mathrm{Rb} / \mathrm{Sr}$ ratios and the negative $\mathrm{Nb}$ anomalies (Fig. $6 \mathrm{a}$ ) might be attributed to a low degree of partial melting (Plank and Langmuire, 1988), to a crustal contamination (Weaver et al., 1987), or to melts derived from a metasomatically enriched mantle source (Richardson et al., 1982).

The enrichment in LILE might be associated to the introduction of slab-derived materials and/or to the transfer of subductionrelated fluids. Such fluids are originated by dehydration of the descending oceanic crust and the rise into the overlying depleted mantle wedge (Pearce, 1983). The resultant melt should have a geochemical trace element pattern similar to volcanic-arc related magmas (Saunders et al., 1980).

The effect of contamination of a primitive melt by crustal material is tested with a $\mathrm{Cr}+\mathrm{Ni}$ vs $\mathrm{K}$ plot (Fig. 6e). $\mathrm{Cr}$ and $\mathrm{Ni}$ are compatible elements in mafic minerals, while $\mathrm{K}_{2} \mathrm{O}$ is a highly incompatible component. Normal fractional crystallization in a closed system should follow a hyperbolic curve in this diagram (Pearce, 1982). The investigated dykes show a scattered behavior and do not exhibit a hyperbolic trend in the diagram, suggesting that crustal contamination might have played a certain role during magma evolution. Moreover, the wide variation of $\mathrm{Rb}$ contents of the trachyandesitic samples (41.7-152.5 ppm) also supports the idea that a contamination with LILE-enriched crustal material might have occurred. The assimilation of the country rocks could have taken place either at deep or at shallow levels in the crust. Our field evidence also support country rock assimilation by the dykes (Fig. 3f and section 3.2).

$\mathrm{Ni}, \mathrm{Cr}$ and $\mathrm{Mg \#}$ of the dykes are much lower than primary mantle melts (>250 ppm Ni, >1000 ppm Cr, >65 Mg\#; Perfit et al., 1980; Wilson, 1989). The absence of primitive rocks among the studied dykes might be attributed to magma mixing and/or to some fractional crystallization processes, before their emplacement. There is no field evidence that support magma mixing processes in the evolution of the mesosilisic dykes.

The patterns of incompatible elements as well as the REE patterns are similar in the rocks of the swarm. The patterns of the three types of rocks (basaltic trachyandesite, trachyandesite and trachyte) are parallel and have similar values (Fig. 6b). Also the three types have, in general, a similar negative $\mathrm{Nb}, \mathrm{Zr}$ and $\mathrm{Ti}$ anomalies (Fig. 6a) suggesting that their composition has been modified at some point by fractional crystallization processes. It is also indicated that plagioclase was not a predominant crystallizing phase due to the small values of Eu/Eu* in the samples (Fig. 6d; Basaltic Volcanism Study Project, 1981). Amphibole fractionation decreases the M-REE and leads to a concave upward curve in normalized REE diagrams (Hanson, 1980).

\subsubsection{Rhyolitic dykes}

The REE pattern for the rhyolitic dykes is characterized by unfractionated flat HREE (Fig. 6b) suggesting a garnet-free source. The felsic dyke rocks might have been formed by simple fractional crystallization processes from a garnet-free magma source. Incompatible element diagrams (normalized to N-MORB after Pearce, 1982) for the felsic dykes display patterns strongly modified by fractional crystallization (Fig. 6a). A low content of Sr and the occurrence of strong negative $\mathrm{P}$ and $\mathrm{Ti}$ anomalies in the spider diagram, suggest that significant crystallization of plagioclase, apatite and Ti-magnetite probably took place before emplacement. Thus, the most plausible explanation for the low $\mathrm{Mg}, \mathrm{Cr}$, $\mathrm{Ni}$ and relatively high LILE in the felsic dykes is a fractional crystallization process, rather than a small degree of partial melting from a slightly enriched mantle source.

From the chemical data and the qualitative evolution presented here, it is clear that the trachyandesitic and rhyolitic dyke groups cannot be related to fractional crystallization processes from a common parental magma. Therefore, dissimilar parental magmas, each one with its own subsequent evolution, might have been responsible for the suites of rocks found in the swarm.

Based on the lack of geochronological data from the rhyolitic dykes and the ambiguous similarities with both the Triassic dyke swarm and the Jurassic acidic Marifil Volcanic Complex, we propose two possible scenarios for this early Mesozoic magmatism. The first and simplest one is taking into account that the rhyolites are younger and have no genetic or temporal relation with the trachyandesites of the swarm. The second explanation involves a multi-stage magmatic scenario in which two different sources have been molten in order to generate two different melts. One of the melts might have been formed from a deeper garnet-bearing source before rising through the crust and assimilating parts of its country rocks. The second magma might have been differentiated in the continental crust from a garnet-free source. The upper reservoir from the acidic magma might have been energized by the rising of the deeper primitive magma causing the emplacement of the swarm at shallow levels of the crust. This possibility allows us to put together the different rocks of the swarm at the same time and in the same location, in order to explain their geological relation in the field. 

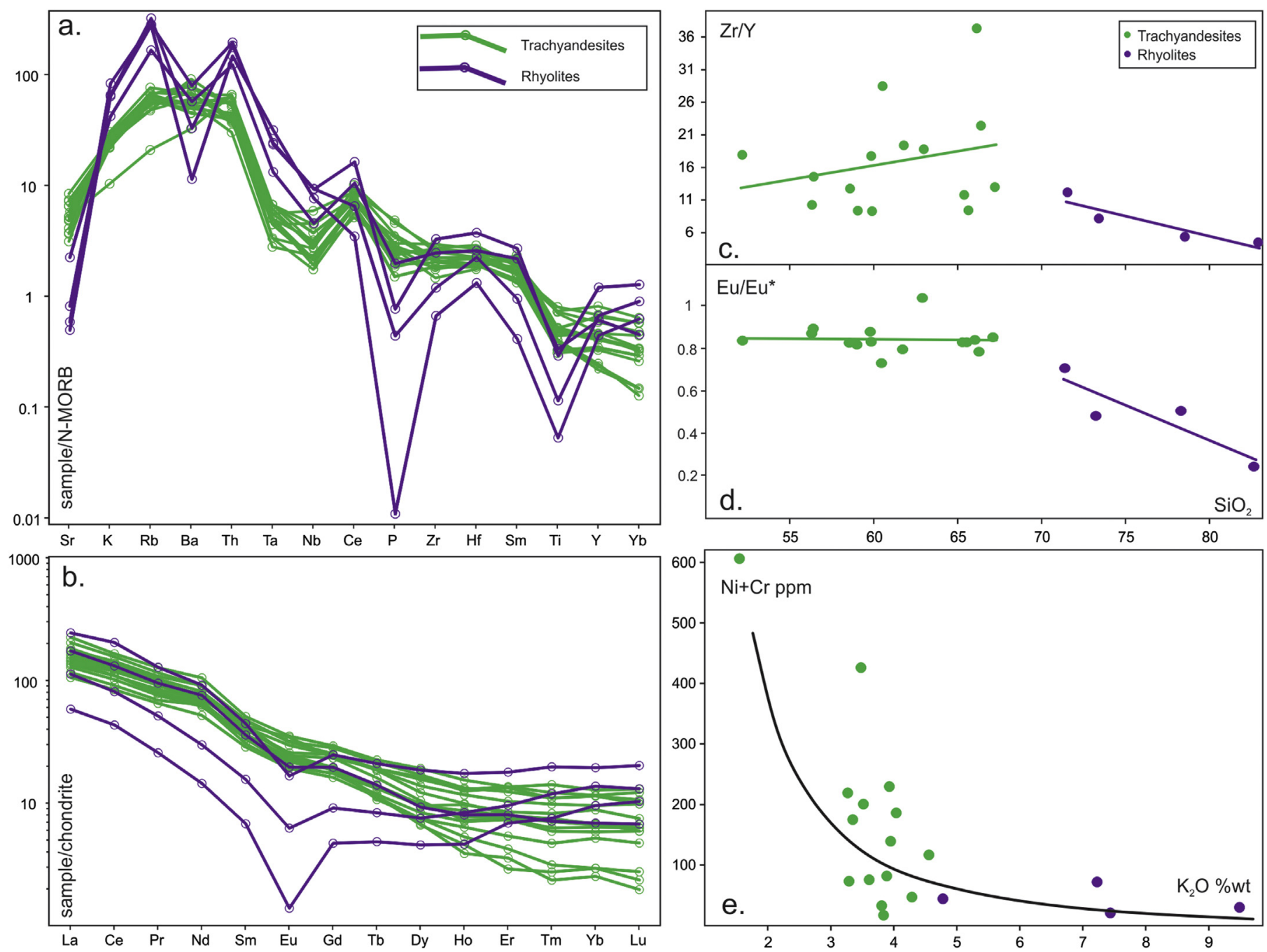

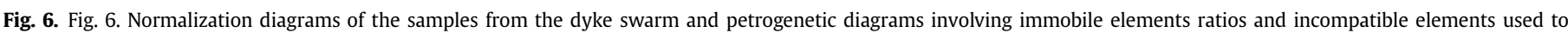

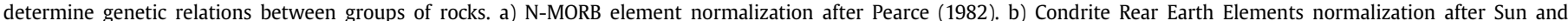

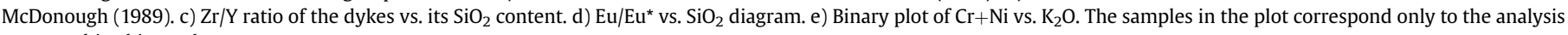
presented in this work.

\subsection{Tectonic and geodynamic significance of the dyke swarm}

The geotectonic settings where dyke swarms have been intruded are diverse and all of them imply an extensional tectonic regime. Furthermore, the geochemistry of the igneous rocks from such environments is particular and reflects some characteristics of the source. These characteristics can be used to approach the precise tectonic environment where the magma has been generated and consequently evolved.

As shown above, the rocks in the swarm belong to the High-K group in the $\mathrm{K}_{2} \mathrm{O}$ versus $\mathrm{SiO}_{2}$ diagram (Fig. 5). Additionally the Peacock index and the $\mathrm{Na}_{2} \mathrm{O}+\mathrm{K}_{2} \mathrm{O}$ values of the trachyandesites indicate that the samples have a transitional behavior between the subalkaline and alkaline series of rocks (Fig. 4d). These geochemical characteristics are typical of the youngest subduction-related magmas (Morrison, 1980). The REE patterns (Fig. 6b) and the high $\mathrm{La} / \mathrm{Lu}_{\mathrm{N}}$ ratios are typical of magmatic arc related rocks. Incompatible trace element patterns of the dykes, both trachyandesitic and rhyolitic, are characterized by a relative depletion in $\mathrm{Nb}, \mathrm{P}$ and $\mathrm{Ti}$ (Fig. 6a), typical of subduction-related calcalkaline magmas. They also exhibit a relative $\mathrm{Sr}$ depletion and enrichment in $\mathrm{Ba}, \mathrm{Rb}$ and $\mathrm{K}$ which defines the slab derived component (Gill, 2010). However, we cannot distinguish whether the arc-like signature in the trace element patterns has been inherited from the metasomatized mantle source (Pearce, 1983; Thirlwall et al., 1994), or reflects contamination by continental crust depleted in HFSE relative to LILE (Weaver and Tarney, 1984; Taylor and McLennan, 1995).

The chemical characteristics of the investigated dyke swarm are similar to the continental arc rocks as it is shown by tectonic discrimination diagrams (Fig. 7; Gorton and Shandl, 2000). Gorton and Schandl's (2000) geotectonic discrimination diagram (Fig. 7) was developed for acidic and mesosilicic rocks using element ratios sensitive to the petrogenetic process of the different geotectonic settings. The dyke samples plot mostly in the volcanic arc field of the diagrams but some samples plot in the within-plate field.

The rhyolitic dyke samples plot in the discrimination diagrams as orogenic to within-plate settings. Sylvester (1989) found that post-collisional granites show affinities with volcanic arc granites and are compositionally similar to syn-collisional and within-plate granites. This author proposes the transitional member "Highly fractionated I- and S-Type granite" between the "Normal I- and Stype granites" and the "A-type granites". Fig. 8 shows that the trachyandesitic dykes belong to the "Normal I- and S-type" and are transitional to the "Highly fractionated" and "A-type" granites. 

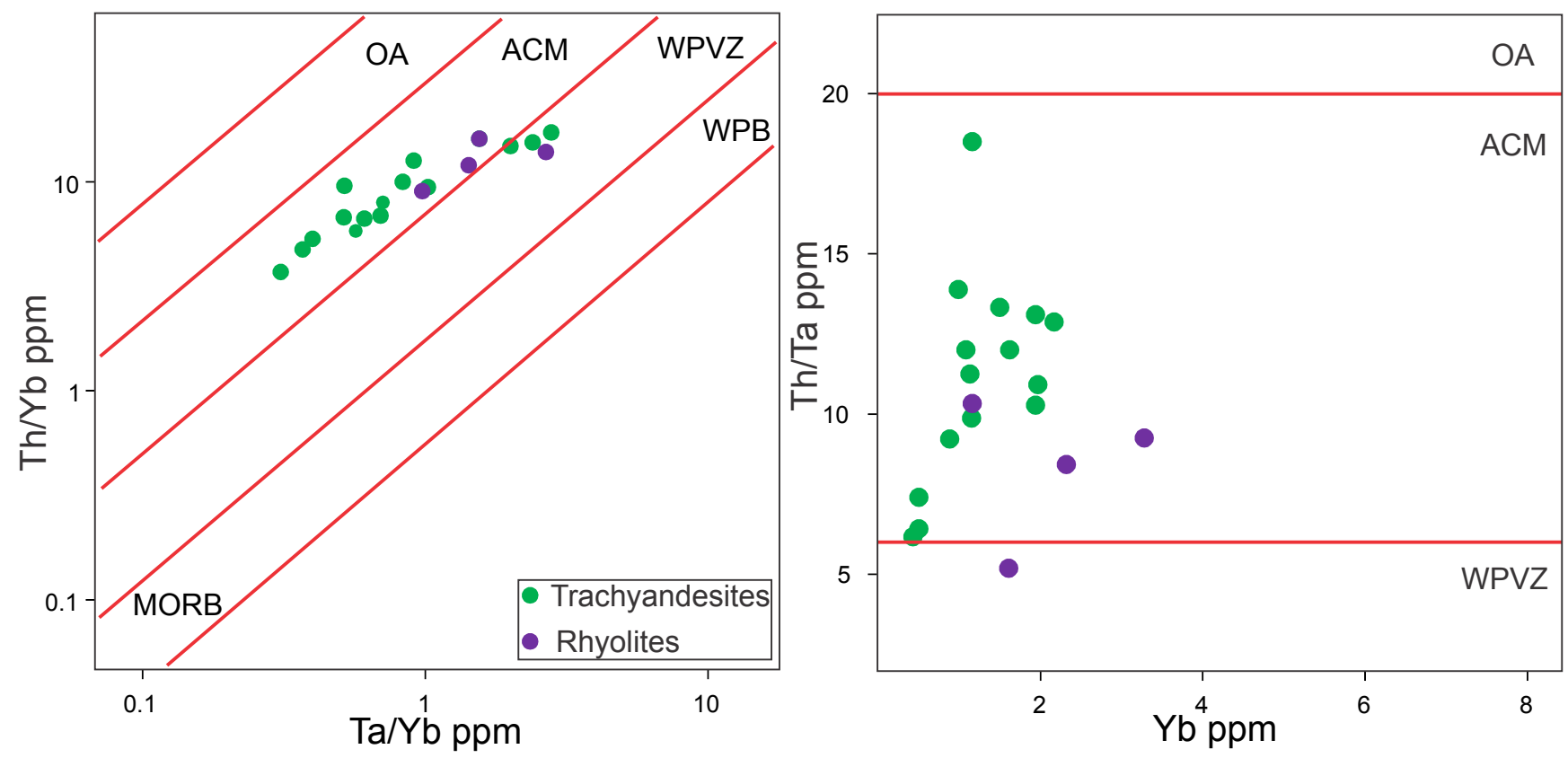

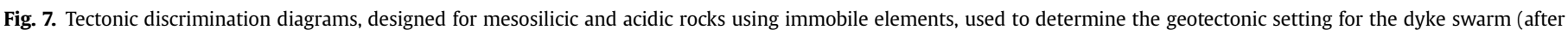
Gorton and Shandl (2000)). OA: oceanic arc; ACM: active continental margin; WPVZ: within plate volcanic zone; WPB: within plate basalt; MORB: mid-ocean ridge basalt.

Meanwhile, the rhyolitic dykes are more similar to "Highly fractionated" and "A-type". The rhyolites may represent an extremely differentiated subduction-related melt besides the trachyandesites. They might belong to a product of partial melting from a sublithospheric mantle.

In an active continental margin setting there are a few processes capable to explain both an extensional tectonic regime and a large magma production. Lithospheric delamination (Bird, 1979; Black and Liegéois, 1993) and slab break-off (Liégeois and Black, 1987; von Blanckenburg and Davies, 1995) are the main mechanisms proposed to explain a postorogenic magmatism. In both cases the isostatic instability of the orogen leads to an extensional process in order to compensate the gravitational anomaly. At the same time an ascendant current from the asthenosphere produces the fusion of the subcontinental lithospheric mantle. Additionally, an accumulation of magma can occur at the base of the lithosphere (underplating) and would generate partial melting of the lower crust.

The magmas generated in a post-orogenic stage will display a mixed signature between arc-related magmatism and anorogenic magmatic suites. The enriched mantle wedge might be the source for the postorogenic magmatism. In this stage the water supply is not as permanent and abundant as it was during the subduction stage. The lack of water might explain both a lower degree of partial melting and the mildly-alkaline signature of the generated magmas in this stage.

The above features for postorogenic processes could explain the chemical characteristics of the dykes studied here and the geotectonic environment during their emplacement. The geochemical signatures of the dykes reflect the inheritance of a continental magmatic-arc setting and show transitional features to postcollisional or anorogenic tectonic settings. The stratigraphic relations of the dyke swarm argue for a subduction-related postorogenic environment. The swarm cuts both the magmatic arc rocks (represented by the Paileman Plutonic Complex (Giacosa, 1993; Busteros et al., 1998; Varela et al., 2009; García et al., 2014a)) and the orogenic deformational structures (represented by the El Jagüeglito and Peñas Blancas shear zones (Giacosa, 2001)).
Additionally, the tensional regime required for the rise and emplacement of magmas can be related to a postorogenic stage.

\subsection{Correlations with other North Patagonian units}

In northern outcrops of Patagonia, the Permian plutonic complexes of La Esperanza (Llambías and Rapela, 1984), Pailemán (Giacosa, 1993), and Navarrete (Caminos, 1983, 1998) were recognized as the Gondwanic magmatic arc (Pankhurst et al., 2006; Ramos, 2008). These complexes intruded the early Paleozoic plutonic and metamorphic rocks.

In the middle-northern North Patagonian Massif, the Permian plutonic units are intruded by plutons and covered by volcanic rocks of Late Permian to Early Triasic age (Llambías and Rapela, 1984). The Triassic Collinao ignimbritic dacite (U-Pb SHRIMP zircon age $246 \pm 2$ Ma in Pankhurst et al., 2006) covers over an erosion surface above Permian La Esperanza Plutonic Complex (U-Pb circon age $271 \mathrm{Ma}$ in Pankhurst et al., 2006). The Calvo Granite intrude the Permian plutons and is $250 \pm 2 \mathrm{Ma}$ (U-Pb circon age in Pankhurst et al., 2006). This granite was considered as postmagmatic to the Permian plutonism on the basis of its geochemical features (as highly fractionated orogenic granite) and intrusive relations (Martínez Dopico et al., 2013). Overlaying the Permian to Early Triassic rocks there is a thick volcanic and volcaniclastic sequence of Middle Triassic to Jurassic age corresponding to the Los Menucos Volcanic Complex (Lema et al., 2008).

The previously described stratigraphic relations are similar to those found in the study are between the Permian granites, the Triassic dyke swarmn and the Marifil Volcanic Complex. Moreover, the basal andesitic lava flows from Marifil Volcanic Complex were proposed as Triassic (Rosenman, 1972; Malviccini and Llambías, 1974; Cortés, 1981; Giacosa, 1993).

\subsection{Geotectonic implicances}

In the eastern North Patagonia Massif, the finalization of the Gondwanide orogenic compression and related magmatism is evidenced in two geological elements: the erosive surface between 

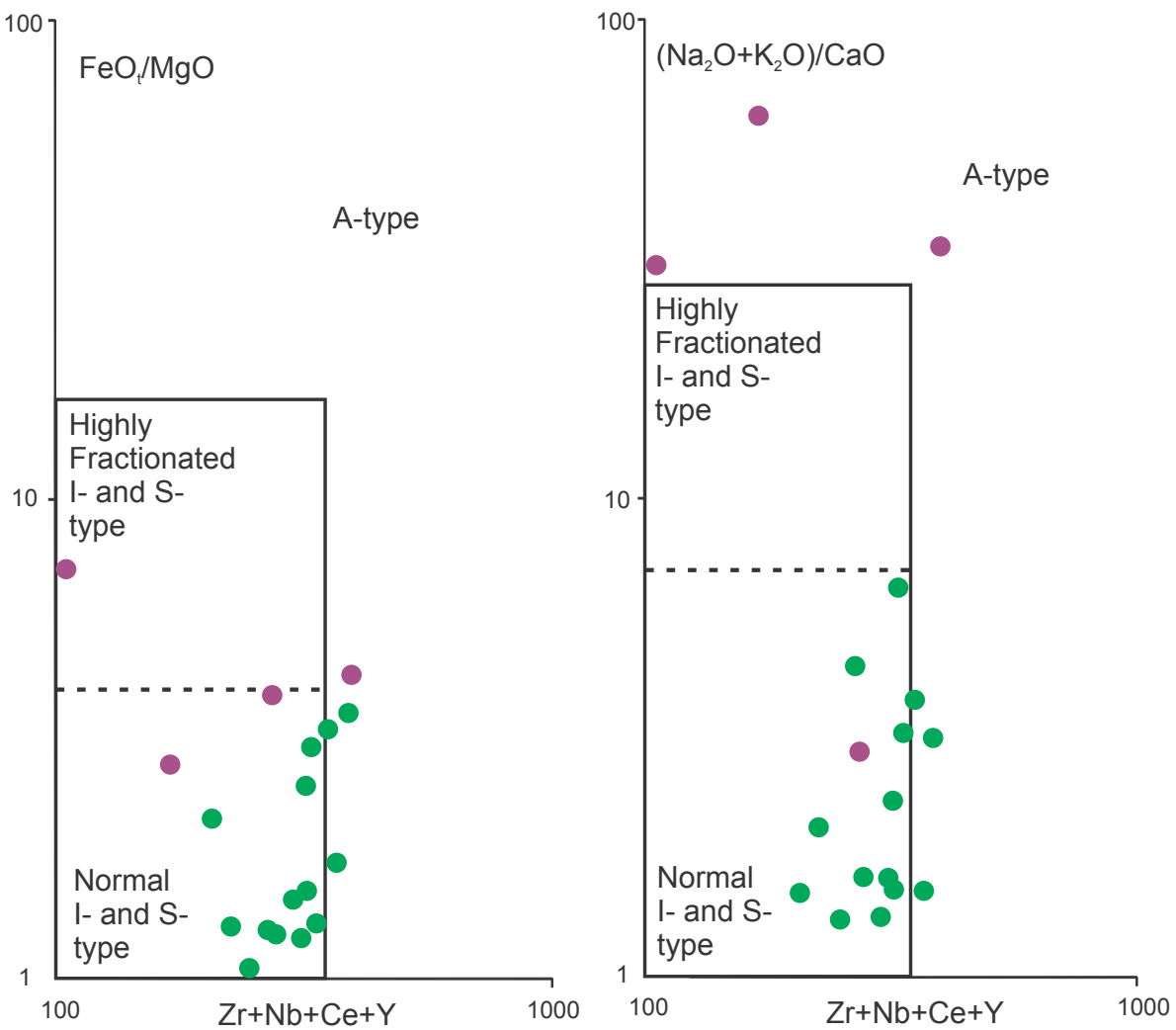

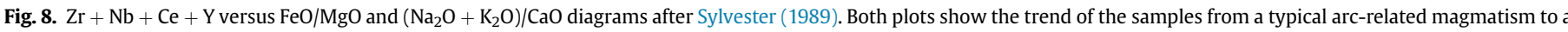
post-collisional or anorogenic magmatism.

the Permian plutonic rocks and the Mesozoic volcanic rocks, and the NW dyke swarm. Both elements are related to a Triassic extensional tectonic regime.

In the Fig. 9 there is a proposal of the tectonic evolution for the eastern North Patagonian Massif between the Permian and Triassic During the Gondwanide orogeny the compression has been proposed in a NE-SW direction (Fig. 9a; von Gosen, 2002). This orientation explains the NW-SE trend of the deformational

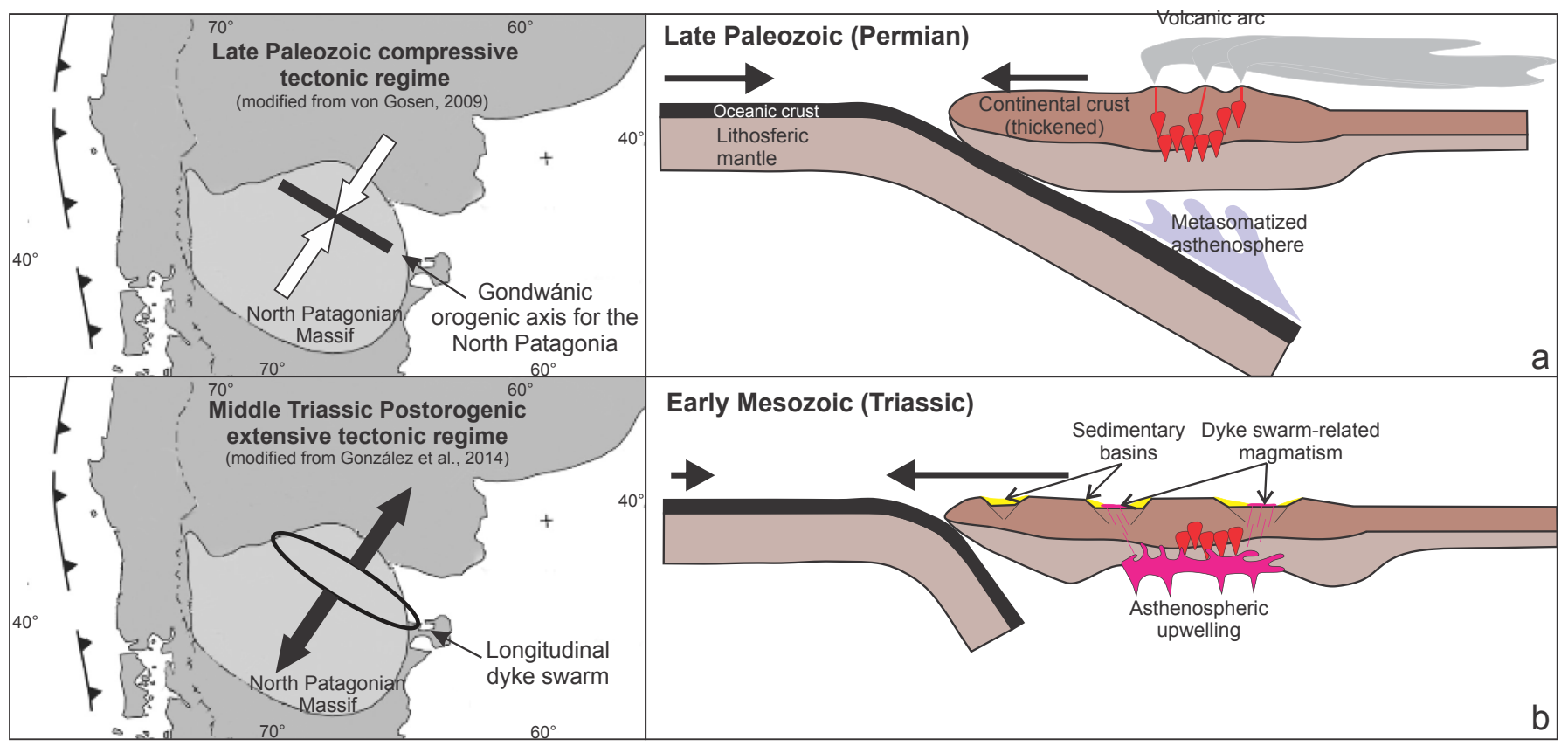

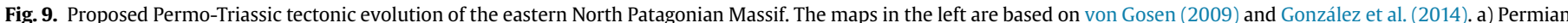

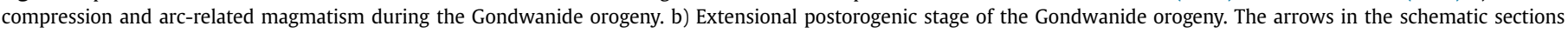
indicate the possible vector of relative convergence between the plates. 
structures and the alignment observed in the associated plutons (Llambías and Rapela, 1984; Rapela and Llambías, 1985).

Through Early Triassic the subduction regimen change, probably because the convergence slow down or stop, and consequently the compression vector change (Fig. 9b). As the dyke swarm is oriented parallel to the Gondwanide orogenic axis, the Triassic extension should have had a NE-SW orientation (Fig. 9).

We propose a postorogenic event, related to the collapse of the Gondwanide orogen, as responsible for the Triassic extension. This event might have been related to the beginning of the Pangea break-up.

\section{Conclusions}

In summary, we can draw the following conclusions in relation to the magmatic processes and evolution of the Triassic dyke swarm in the eastern North Patagonian Massif:

1. The Triassic dyke swarm is composed mainly of trachyandesite and trachytes with minor basaltic trachyandesite. The genetic relation between the rhyolitic and the trachyandesitic dykes of the swarm remains unclear.

2. The dykes in the swarm belong to mildly alkaline, high-K, rock series and have a transitional geochemical signature between a typical magmatic arc and anorogenic tectonic setting.

3. The trachyandesitic dykes have a geochemical signature from a garnet-bearing source and the rhyolitic dykes seem to have been originated from a garnet-free source.

4. The stratigraphic relations indicate that the swarm is younger than the deformation and magmatism of the Gondwanide orogeny. The extensional structures where the dykes are hosted are subparallel to the compressive Permian structures. The extensional tectonic event is probably related to the collapse of the Permian orogen.

5. The Triassic dyke swarm belongs to a postorogenic process linked to the final stage of the Permian Gondwanic orogeny.

6. The Anisian postorogenic process started in an extensional tectonic regime at the southwestern margin of Gondwana and can be related to the break-up of Pangea.

\section{Acknowledgments}

We would like to express our sincere thanks to the people from Sierra Grande to Gonzalito areas, all over the wide eastern part of Río Negro province, for allowing us the access to their farms and for their hospitality during our field work. We are grateful to W. von Gosen for him constructive review that helped to improve the present manuscript. Fieldwork and laboratory task were possible by the financial contributions of the Universidad Nacional de La Plata (UNLP Project $11 / \mathrm{N} \mathrm{653)}$ ) and Consejo Nacional de Investigaciones Científicas y Técnicas (PIP-CONICET 0119).

\section{References}

Basaltic Volcanism Study Project (BVSP), 1981. Basaltic Volcanism on the Terrestria Planets. Pergamon Press, New York, p. 1286.

Bird, P., 1979. Continental delamination and the Colorado plateau. J. Geophys. Res. Solid Earth 1978-2012 84 (B13), 7561-7571.

Black, R., Liégeois, J.P., 1993. Cratons, mobile belts, alkaline rocks and continental lithospheric mantle: the Pan-African testimony. J. Geol. Soc. Lond. 150, 89-98.

Busteros, A., Giacosa, R., Lema, H., 1998. Hoja Geológica 4166-IV, Sierra Grande (Río Negro). Instituto de Geología y Recursos Minerales, Servicio Geológico Minero Argentino. Boletín $N^{\circ}$ 241, Buenos Aires, p. 75.

Caminos, R., 1983. Informe preliminar de las Hojas 39-g, Cerro Tapiluke y 39-h, Chipauquil, provincial de Río Negro. Servicio Geológico Nacional, Buenos Aires, p. 41 (unpublished).

Caminos, R., 1998. Hoja geológica 4166-I, Valcheta. Instituto de Geología y Recursos Minerales, Servicio Geológico Minero Argentino, Buenos Aires, p. 95 (unpublished).

Caminos, R. 2001. Hoja Geológica 4166-I, Valcheta. Provincia de Río Negro. Instituto de Geología y Recursos Minerales. Servicio Geológico Minero Argentino. Boletín 299, Buenos Aires, p. 71

Carracedo, M., Larrea, F.J., Alonso Olazabal, A., Gil Ibarguchi, J.L., 1997. Relación entre las intrusiones plutónicas y el complejo filoniano en el batolito de Los Pedroches (Macizo Ibérico, España): los diques como indicadores de ambientes paleotectónicos y paleoesfuerzos. Cad. do Lab. Xeolóxico Laxe 22, 229-246.

Cawood, P.A., Buchan, C., 2007. Linking accretionary orogenesis with supercontinent assembly. Earth Sci. Rev. 82, 217-256.

Cawood, P.A., 2005. Terra Australis orogen: Rodinia breakup and development of the Pacific and Iapetus margins of Gondwana during the neoproterozoic and paleozoic. Earth Sci. Rev. 69, 249-279.

Chen, J.H., Moore, J.G., 1979. Late Jurassic Independence dike swarm in eastern California. Geology 7, 129-133.

Coleman, D.S., Bartley, J.M., Glazner, A.F., Carl, B.S., 1994. Late Cretaceous dikes in the independence swarm, California. EOS 75, 686.

Cortés, J.M., 1981. El sustrato pre-cretácico del extremo nordeste de la provincia del Chubut. Rev. de la Asoc. Geol. Argent. 36 (3), 217-235.

El-Sayed, M.M., 2006. Geochemistry and petrogenesis of the post-orogenic bimodal dyke swarms in NW Sinai, Egypt: constraints on the magmatic-tectonic processes during the late Precambrian. Chem. Erde 66, 129-141.

Féraud, G., Alric, V., Fornari, M., Bertrand, H., Haller, M., 1999. The Mesozoic silicic volcanic Province of Patagonia synchronous with the Gondwana Break-up and subduction: space-time evolution evidenced by 40Ar/39Ar data. Earth Planet. Sci. Lett. 172, 83-96.

García, V.A., González, S.N., Tassinari, C.C.G., Sato, K., Sato, A.M., González, P.D. Varela, R., 2014a. U/Pb and Nd data from Peñas Blancas pluton, Northpatagonian Massif, Argentina. In: 9th South American Symposium on Isotope Geology. São Paulo, Brasil. Actas: 190.

García, V.A., González, S.N., Tassinari, C.C.G., Sato, K. Sato, A.M., González, P.D. Varela, R., 2014b. Geoquímica y Geocronología del Plutón La Verde, Macizo Nordpatagónico, provincia de Río Negro. XIX Congreso Geológico Argentino Córdoba, República Argentina.

Giacosa, R., 1987. Caracterización de un sector del basamento metamórfico-migmatítico en el extremo suroriental del Macizo Norpatagónico. In: Provincia de Río Negro, Argentina., $10^{\circ}$ Congreso Geológico Argentino, Actas 3: 51-54, S. M. de Tucumán.

Giacosa, R., 1993. El ciclo eruptivo Gondwánico en el área de Sierra de Pailemán, Macizo Norpatagónico, Argentina. In: $12^{\circ}$ Congreso Geológico Argentino y $2^{\circ}$ Congreso de exploración de Hidrocarburos, Actas 4: 113-119, Buenos Aires.

Giacosa, R., 1994. Geología y petrología de las rocas pre-cretácicas del área arroyo Salado - Arroyo Tembrao, sector oriental del Macizo Nordpatagónico, Río Negro. $\mathrm{PhD}$ Thesis. Universidad Nacional de la Patagonia San Juan Bosco, Comodoro Rivadavia, Chubut - Argentina, p. 129 (unpublished).

Giacosa, R., 2001. Zonas de cizalla frágil-dúctil neopaleozoicas en el nordeste de la Patagonia. Rev. la Asoc. Geol. Argent. 56 (2), 131-140.

Gill, R., 2010. Igneous Rocks and Processes, a Practical Guide. Wiley-Blackwell, Malaysia, p. 428

González, P.D., Varela, R., Sato, A.M., Llambías, E.J., González, S., 2008. Dos fajas estructurales distintas en el Complejo Mina Gonzalito (Río Negro). In: 17º Congreso Geológico Argentino, Actas 2: 847-848, San Salvador de Jujuy.

González, P.D., Tortello, F., Damborenea, S., 2011. Early Cambrian archaeocyathan limestone blocks in low-grade meta-conglomerate from el Jagüelito Formation (Sierra Grande, Río Negro, Argentina). Geol. Acta 9 (2), 159-163.

González, S.N., Greco, G.A., González, P.D., García, V.A., Llambías, J.E., Sato, A.M., Díaz, P., 2013. Geología de un enjambre longitudinal de diques mesosilícicos en la Patagonia norte. In: $2^{\circ}$ Simposio sobre Petrología Ígnea y Metalogénesis Asociada, Actas: 43, San Luis.

González, S.N., Greco, G.A., González, P.D., Sato, A.M., Llambías, J.E., Varela, R., Basei, M.A.S., 2014. Geología, petrografía y edad U-Pb de un enjambre longitudinal NO-SE de diques del Macizo Nordpatagónico Oriental, Río Negro. Rev. de la Asoc. Geol. Argent. 71 (2), 174-183.

Gorton, M.P., Schandl, E.S., 2000. From continents to island arcs: a geochemical index of tectonic setting for arc-related and within-plate felsic to intermediate volcanic rocks. Can. Mineral. 38, 1065-1073.

Grecco, L.E., Gregori, D.A., Rapela, C.W., Pankhurst, R.J., Labudía, C.H., 1994. Peraluminous granites in the Northeastern sector of the north Patagonian Massif. In: $7^{\circ}$ Congreso Geológico Chileno, Actas 2: 1354-1359, Concepción.

Grecco, L.E., Gregori, D.A., 2011. Geoquímica y Geocronología del Complejo Plutónico Paileman, Comarca Nordpatagónica, Provincia de Río Negro. In: $18^{\circ}$ Congreso Geológico Argentino (CD abstracts, Neuquén).

Greco, G.A., González, S.N., Sato, A.M., Basei, M.A.S., González, P.D., 2014. Nueva datación en circones detríticos para el Complejo Mina Gonzalito, Provincia de Río Negro. In: $19^{\circ}$ Congreso Geológico Argentino, Actas. Córdoba - Argentina.

Greco, G.A., González, P.D., González, S.N., Sato, A.M., Basei, M.A.S., Tassinari, C.C.G., Sato, K., Varela, V., Llambías, E.J., 2015. Geology, structure and age of the Nahuel Niyeu formation in the Aguada Cecilio area, North Patagonian Massif, Argentina. J. S. Am. Earth Sci. 62, 12-32.

GSA Geologic Time Scale v4.0 (http://www.geosociety.org/science/timescale)

Hanson, G.N., 1980. Rare earth elements in petrogenetic studies of igneous systems. Ann. Rev. Earth Planet. Sci. 8, 371-406.

IUGS International Chronostratigraphic Chart v2015/01 (http://www.stratigraphy. org/index.php/ics-chart-timescale).

Japas, M.S., 2001. Modelo cinemático neopaleozoico para el sector nororiental del 
Macizo Norpatagónico, Argentina. J. Iber. Geol. 27, 91-121.

Kay, S.M., Ramos, V.A., Mpodozis, C., Sruoga, P., 1989. Late paleozoic to jurassic silicic magmatism at the Gondwana margin: analogy to middle Proterozoic in north America? Geology 17, 324-328.

Keidel, J., 1921. Sobre la distribución de los depósitos glaciares del Pérmico conocidos en la Argentina y su significación para la estratigrafía de la serie del Gondwana y la paleogeografía del Hemisferio Austral. Acad. Nac. Ciencias, Bol. 25, 239-368 (Córdoba).

Le Maitre, R.W., 2002. Igneous Rocks: a Classification and Glossary of Terms, second ed. Cambridge University Press.

Lema, H., Busteros, A., Giacosa, R., Cucchi, R., 2008. Geología del Complejo Volcánico Los Menucos en el área tipo - Río Negro. Rev. la Asoc. Geol. Argent. 63 (1), $3-13$.

Liégeois, J.P., Black, R., 1987. Alkaline magmatism subsequent to collision in the PanAfrican belt of the Adrar des Iforas (Mali). In: Fitton, J.G., Upton, B.J.G. (Eds.), Alkaline Igneous Rocks, Geological Society Special Publication, London, vol. 30, pp. 381-401.

Llambías, E.J., Rapela, C.W., 1984. Geología de los complejos eruptivos del Paleozoico superior de La Esperanza, provincia de Río Negro. Rev. de la Asoc. Geol. Argent. 39, 220-243.

Llambías, E.J., Sato, A.M., 1990. El Batolito de Colangüil (29-31º S) Cordillera Frontal de Argentina: estructura y marco tectónico. Rev. Geol. Chile 17 (1), 89-108.

Llambías, E., Sato, A.M., 2011. Ciclo Gondwanico: la provincia magmatica Choiyoi en Neuquén. In: Relatorio XVIII Congreso Geológico Argentino, pp. 53-62.

Llambías, E., Varela, R., Sato, A.M., 2002. Deformación y metamorfismo neopaleozoico en Yaminué, Macizo Norpatagónico $\left(40^{\circ} 50^{\prime} \mathrm{S}, 67^{\circ} 40^{\prime} \mathrm{O}\right)$ : su relación con la Fase Orogénica San Rafael y el arco de los Gondwánides. In: $15^{\circ}$ Congreso Geológico Argentino, 3: 123-128. El Calafate.

Malvicini, L., Llambías, E., 1974. Geología y génesis del depósito de manganeso Arroyo Verde, provincia del Chubut, República Argentina. In: $5^{\circ}$ Congreso Geológico Argentino, Actas 2: 185-202, Villa Carlos Paz.

Martínez Dopico, C., López de Luchi, M., Rapalini, A., 2013. Comparación de la mineralogía de las biotitas de algunos granitoides permo-triásicos del norte de Patagonia. In: $2^{\circ}$ Simposio sobre Petrología Ígnea y Metalogénesis Asociada, Actas: 62-63, San Luis.

Morrison, G., 1980. Characteristics and tectonic settings of shoshonitie rock association. Lithos 13, 97-108.

Naipauer, M., Sato, A., González, P.D., Chemale jr., F., Varela, R., Llambías, E., Greco, G., Dantas, E., 2010. Eopaleozoic Patagonia-East Antarctica connection: fossil and $\mathrm{U}-\mathrm{Pb}$ evidence from el Jagüelito Formation. In: 7th South American Symposium Isotope Geology, vol. 602-605 (Brasilia).

Pankhurst, R.J., Leat, P.T., Sruoga, P., Storey, B.C., Rapela, C.W., Riley, T.R., Marquez, M., 1998. The Chon Aike province of Patagonia and related rocks in West Antarctica: a silicic large igneous province. J. Volcanol. Geotherm. Res. 81, $113-136$.

Pankhurst, R.J., Rapela, C.W., Fanning, C.M., Márquez, M., 2006. Gondwanide continental collision and the origin of Patagonia. Earth Sci. Rev. 76, 235-257.

Parat, F., Dungan, M.A., Lipman, P.W., 2005. Contemporaneous trachyandesitic and calc-alkaline volcanism of the Huerto andesite, san Juan volcanic field, Colorado, USA. J. Petrol. 46 (5), 859-891.

Peacock, M.A., 1931. Classification of igneous rock series. J. Geol. 39, 54-67.

Pearce, J.A., 1980. Geochemical evidence for the genesis and eruptive setting of lavas from Tethyan ophiolites. In: Proceedings of the International Ophiolite Symposium, Nicosia, Cyprus, pp. 201-272.

Pearce, J.A., 1982. Trace element characteristics of lavas from destructive plate boundaries. In: Thorpe, R.S. (Ed.), Andesites. Wiley, Chichester, pp. 525-548.

Pearce, J.A., 1983. Role of the sub-continental lithosphere in magma génesis at active continental margins. In: Hawkesworth, C.J., Norry, M.J. (Eds.), Continental basalts and Mantle Xenoliths. Shiva, Nantwich, pp. 230-249.

Pearce, J.A., Cann, J.R., 1973. Tectonic setting of mafic volcanic rocks determined using trace element analysis. Earth Planet. Sci. Lett. 19, 290-300.

Pearce, J.A., Norry, M.J., 1979. Petrogenetic implications of Ti, Zr, Y, and Nb variation in volcanic rocks. Contrib. Min. Pet. 69, 33-47.

Perfit, M.R., Gust, D.A., Bence, A.E., Arculus, R.J., Taylor, S.R., 1980. Chemical characteristics of island-arc basalts - implications for mantle sources. Chem. Geol. 30 (3), 227-256.

Plank, T., Langmuire, C.H., 1988. An evaluation of the global variations in the major element chemistry of arc basalts. Earth Plant. Sci. Lett. 90, 349-370.

Ramos, V., 1975. Geología del sector oriental del Macizo Norpatagónico entre Aguada Capitán y la Mina Gonzalito, provincia de Río Negro. Rev. de la Asoc. Geol. Argent. 30 (3), 274-285.

Ramos, V.A., 1984. Patagonia ¿un continente paleozoico a la deriva?. In: Actas $9^{\circ}$ Congreso Geológico Argentino, 2: 311-325. Buenos Aires.

Ramos, V., Kay, S., 1991. Triassic Rifting and Associated Basalts in the Cuyo Basin, Central Argentina. GSA special paper 265.

Ramos, V.A., 2008. Patagonia: a paleozoic continent adrift? J. S. Am. Earth Sci. 26 (3), $235-251$.

Rapela, C., Llambías, E., 1985. Evolución magmática y relaciones regionales de los complejos eruptivos de La Esperanza, prov. de Río Negro. Rev. de la Asoc. Geol. Argent. 40 (1-2), 4-25.

Rapela, C.W., Pankhurst, R.J., 1995. El volcanismo riolítico del noreste de la Patagonia: un evento meso-Jurásico de corta duración y origen profundo. In: XII
Congreso Geológico Argentino y II Congreso de Exploración de Hidrocarburos, Actas (IV): 179-188.

Richardson, S.H., Erlank, A.J., Duncan, A.R., Reid, D.L., 1982. Correlated Nd, Sr and Pb isotope variations in Walvis Ridge basalts and implications for the evolution of their mantle source. Earth Planet. Sci. Lett. 59, 327-342.

Riley, T.R., Leat, P.Y., Pankhurst, R.J., Harris, C., 2001. Origins of large volume rhyolitic volcanism in the Antartic Peninsula and Patagonia by crustal melting. J. Petrol. 42 (6), 1043-1065.

Rock, N.M.S., 1987. The nature and origin of lamprophyres: an overview. In: Fiton, J.G., Upton, B.G.J. (Eds.), Alkaline Igneous Rocks, Geol. Soc. Spec. Pub, vol. 30, pp. 191-226.

Rosenman, H.L., 1972. Geología de la región del Arroyo Los Berros (vertiente oriental de la Sierra de Somuncurá), Río Negro, Argentina. Rev. de la Asoc. Geol. Argent. 27 (1), 117-137.

Sato, A.M., Llambías, E.J., Basei, M.A.S., Castro, C.E., 2015. Three stages in the Late Paleozoic to Triassic magmatism of southwestern Gondwana, and the relationships with the volcanogenic events in coeval basins. J. S. Am. Earth Sci. 63, 48-69.

Saunders, A.D., Tarney, J., Weaver, S.D., 1980. Traverse geochemical variations across the Antarctic Peninsula: implications for calc-alkaline magma genesis. Earth Planet. Sci. Lett. 46, 344-360.

Shand, S.J., 1943. The Eruptive Rocks, second ed. Wiley, New York, p. 448.

Sun, S.S., McDonough, W.F., 1989. Chemical and isotopic systematics of oceanic basalts: implications for mantle composition and processes. In: Geological Society of London, Special Publications 1989, vol. 42, pp. 313-345.

Sylvester, P.J., 1989. Post-collisional alkaline granites. J. Geol. 97, 261-280.

Taylor, S.R., McLennan, S.M., 1995. The geochemical evolution of the continental crust. Rev. Geophys. 33 (2), 241-265.

Teixeira, W., Pinese, J.P.P., Iacumin, M., Girardi, V.A.V., Piccirillo, E.M., Echeveste, H., Ribot, A., Fernández, R., Renne, P.R., Heaman, L.M., 2002. Calc-alkaline and tholeiitic dyke swarms of Tandilia, Rio de la Plata craton, Argentina: U/Pb, Sm/ $\mathrm{Nd}$, and $\mathrm{Rb} / \mathrm{Sr} \mathrm{Ar} / \mathrm{Ar}$ data provide new clues for intraplate rifting shortly after the Trans-Amazonian orogeny. Precambrian Res. 119, 329-353.

Thirlwall, M.F., Upton, B.G.J., Jenkins, C., 1994. Interaction between continental lithosphere and the Iceland plume - $\mathrm{Sr}-\mathrm{Nd}-\mathrm{Pb}$ isotope geochemistry of Tertiary basalts, NE Greenland. J. Pet. 35, 839-879.

Thompson, R.N., Morrison, M.A., Hendry, G.L., Parry, S.J., 1984. An assessment of the relative roles of crust and mantle in magma genesis: an elemental approach. In: Philosophical Transactions of the Royal Society, a, vol. 310, pp. 549-590.

Uliana, M.A., Biddle, K.T., Phelps, D.W., Gust, D., 1985. Significado del vulcanismo y extensión mesojurásicas en el extremo meridional de Sudamérica. Rev. de la Asoc. Geol. Argent. 40, 231-325.

Vallés, J., 1978. Los yacimientos minerales ubicados al oeste de la Mina Gonzalito, Departamento San Antonio y Valcheta, Río Negro. Rev. de la Asoc. Geol. Argent. 33 (4), 325-334.

Varela, R., Basei, M., Sato, A., Siga Jr., O., Cingolani, C., Sato, K., 1998. Edades isotópicas $\mathrm{Rb} / \mathrm{Sr}$ y U/Pb en rocas de Mina Gonzalito y Arroyo Salado. Macizo Norpatagónico Atlántico, Río Negro, Argentina. In: $10^{\circ}$ Congreso Latinoamericano de Geología y $6^{\circ}$ Congreso Nacional de Geología Económica, Actas 1: 71-76, Buenos Aires.

Varela, R., Basei, M.A.S., González, P.D., Sato, A.M., Sato, K., 2008. Granitoides famatinianos y gondwánicos en Sierra Grande. In: Nuevas edades radiométricas método U-Pb. Actas 2: 914-915, San Salvador de Jujuy.

Varela, R., Sato, K., González, P.D., Sato, A.M., y Basei, M.A.S., 2009. Geología y geocronología Rb-Sr de granitoides de Sierra Grande, provincia de Río Negro. Rev. la Asoc. Geol. Argent. 64 (2), 275-284.

Varela, R., González, P.D., Basei, M.A.S., Sato, K., Sato, A.M., Naipauer, M., García, V.A., González, S., Greco, G., 2011. Edad del Complejo Mina Gonzalito: revisión y nuevos datos. In: $18^{\circ}$ Congreso Geológico Argentino (CD abstracts, Neuquén).

von Blanckenburg, F., Davies, J.H., 1995. Slab breakoff: a model for syncollisional magmatism and tectonics in the Alps. Tectonics 14, 120-131.

von Gosen, W., 2002. Polyphase structural evolution in the northeastern segment of the North Patagonian Massif (southern Argentina). J. S. Am. Earth Sci. 15, $591-623$.

von Gosen, W., 2009. Stages of Late Palaeozoic deformation and intrusive activity in the western part of the North Patagonian Massif (southern Argentina) and their geotectonic implications. Geol. Mag. 146 (1), 48-71.

Weaver, S.D., Tarney, J., 1984. Empirical approach to estimating the composition of continental crust. Nature 310, 575-577.

Weaver, B.L., Wood, D.A., Tarney, J., Joron, J.L., 1987. Geochemistry of ocean island basalts from South Atlantic: ascension, Bouvet, St. Helena, Gough and Tristan da Cunha. In: Fitton, J.G., Upton, B.G. (Eds.), Alkaline Igneous Rocks. J. Geol. Soc. London Spec. Publ, vol. 30, pp. 253-267.

Wilson, M., 1989. Igneous Petrogenesis. Springer, Netherlands, p. 466.

Winchester, J.A., Floyd, P.A., 1977. Geochemical discrimination of different magma series and their differentiation products using immobile elements. Chem. Geol. $20,325-343$.

Zhang, Chuan-Lin, Zou, Hai-bo, 2012. Comparison between the permian mafic dykes in Tarim and the western part of Central Asian orogenic belt (CAOB), NW China: implications for two mantle domains of the permian Tarim large igneous province. Lithos 174, 15-27. 